\title{
THE CANTERBURY GROUP OF ARCADED GOTHIC EARLY MEDIEVAL CHESTS: A DENDROCHRONOLOGICAL AND COMPARATIVE STUDY
}

\author{
Christopher G Pickvance
}

Christopher G Pickvance, School of Social Policy, Sociology and Social Research, University of Kent, Canterbury, Kent CT2 7NF, UK. Email: C.G.Pickvance@kent.ac.uk

This paper draws attention to an unrecognised group of six pin-hinged, clamped, early medieval chests with gothic arcading in East Kent, England. It provides dendrochronological dates for four of the chests and systematic evidence concerning their construction, decoration and ironwork, including the specific type of lock originally fitted. Comparisons are made with pin-hinged, clamped chests made in some other counties and abroad at roughly the same time. The carved façades contrast with the plain façades of the thirteenth-century chests in Westminster Abbey. The group has the earliest dendro-dated examples thus far of gothic arcading on English clamped chests as well as other distinctive features, suggesting that the chests are the product of a workshop that developed with a degree of independence from other workshops. Their likely origin in Canterbury and a hypothesis about their use are discussed, and topics are identified for future research. This paper aims to provide a solid onecounty base for the comparative study of pin-hinged, clamped chests elsewhere in England.

\section{INTRODUCTION}

This paper will discuss a group of six medieval chests with gothic arcading. Two chests, $A$ and $B$, are at St John's Hospital, Canterbury; the third chest is at All Saints, Graveney; the fourth is at St Peter and St Paul, Boughton under Blean (Iokm from Canterbury); the fifth is at St Mary's, Norton (20km from Canterbury); and the sixth chest is at St Giles, Wormshill (30km from Canterbury). ${ }^{\mathrm{I}}$ A seventh chest - at St Peter and St Paul, Yalding - is used for comparison (figs $\mathrm{I}-7$ ).

Chests are the most common extant type of medieval furniture and today are found mainly in churches, cathedrals and colleges. They can be classified according to their construction type. Four pure types of chest can be distinguished - dug-out, boarded, clamped (the type discussed here), and framed and panelled - but mixed types can be found. ${ }^{2}$ Early writers considered the four types to follow an evolutionary sequence, with

I. The term 'group' implies shared features and distinctiveness relative to other chests. However, how group boundaries are drawn depends on what features are considered most important, which is a subjective judgement. Here, features of construction and decoration are given priority.

2. Chinnery 1979, 69-74, I04-24; Sherlock's (2008) term 'clamped', which goes back to Howard and Crossley (1927, 343), is preferred to Chinnery's 'clamp-fronted' since the boards of all four walls are pegged into long mortises in the broad stiles (uprights). Geddes (I999, 3I) uses the term 'style' ('stile') chest for this type of chest (cf the German term stollentruhe), whereas Eames (I977, I09) uses the term 'hutch'. 


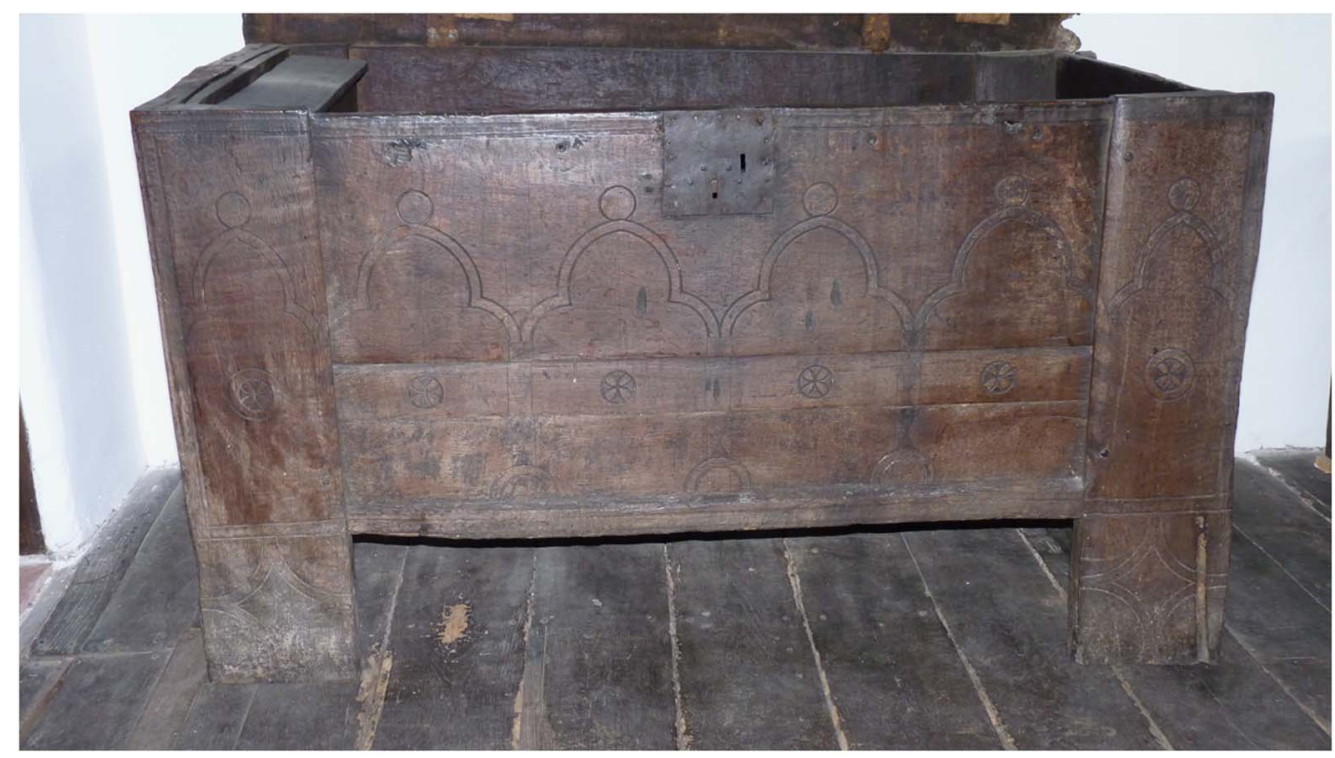

Fig I. St John's chest $A$. Photograph: author.

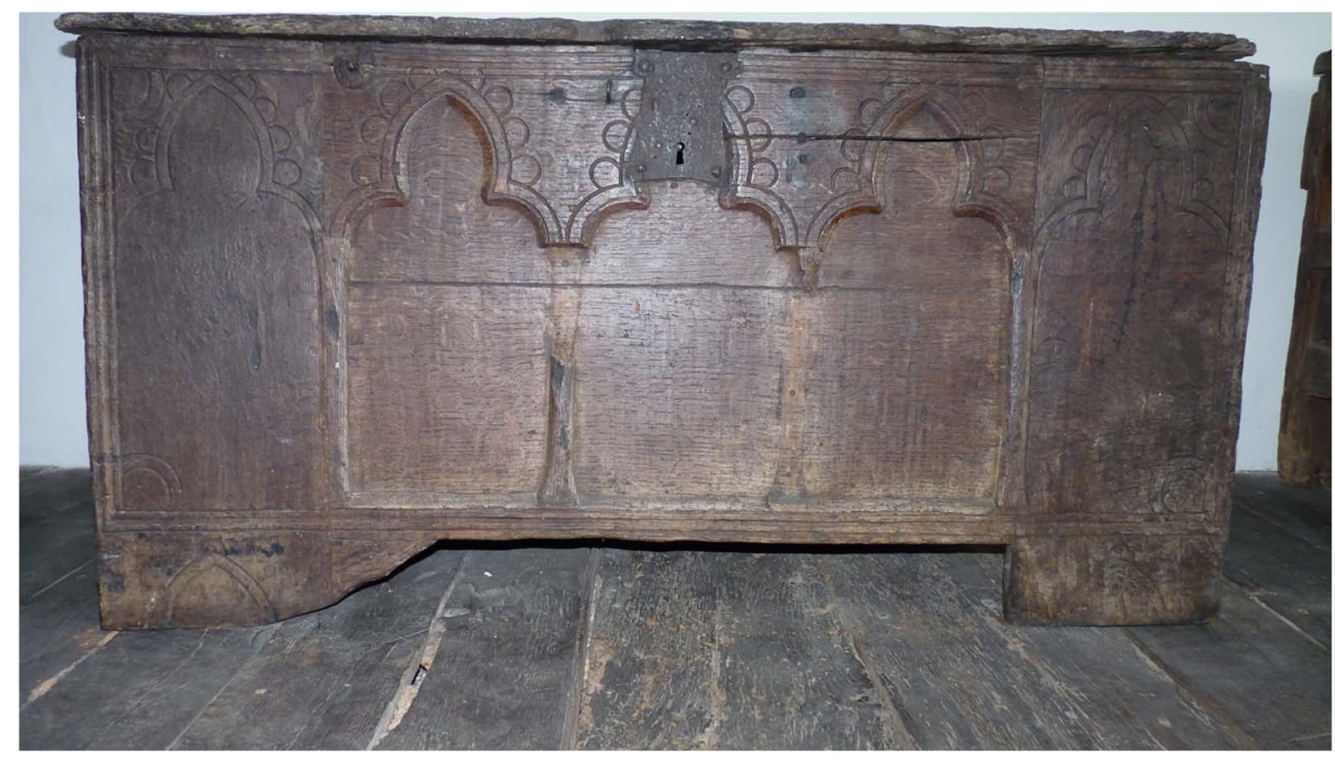

Fig 2. St John's chest B. Photograph: author.

mixed types being labelled 'transitional'. In fact, the four types embody increasing levels of skill, but cost and preferences also affect the choice of type. In England the first three types co-existed in I200. Clamped chests were replaced by framed and panelled chests from the sixteenth century in most areas, dug-out chests were still being made in the seventeenth century and boarded chests continued as a cheap form into the eighteenth century. 


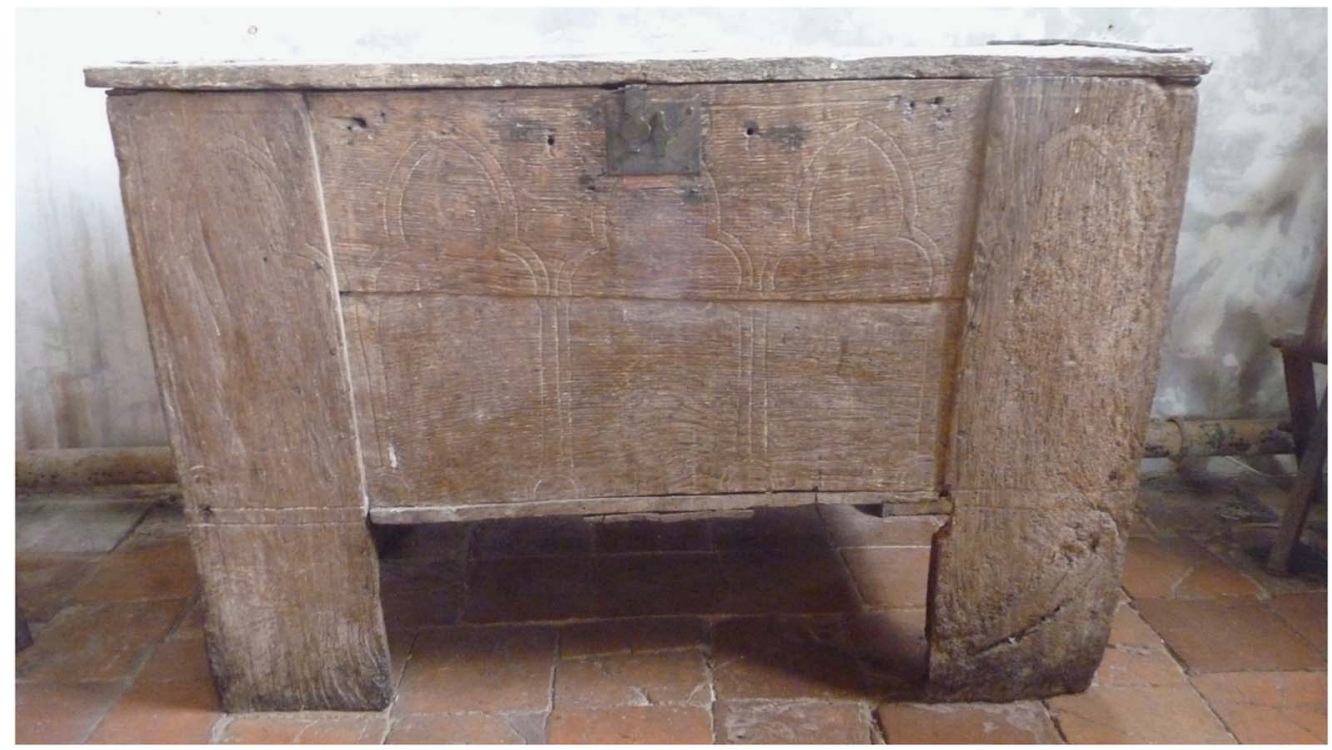

Fig 3. Graveney chest. Photograph: author.

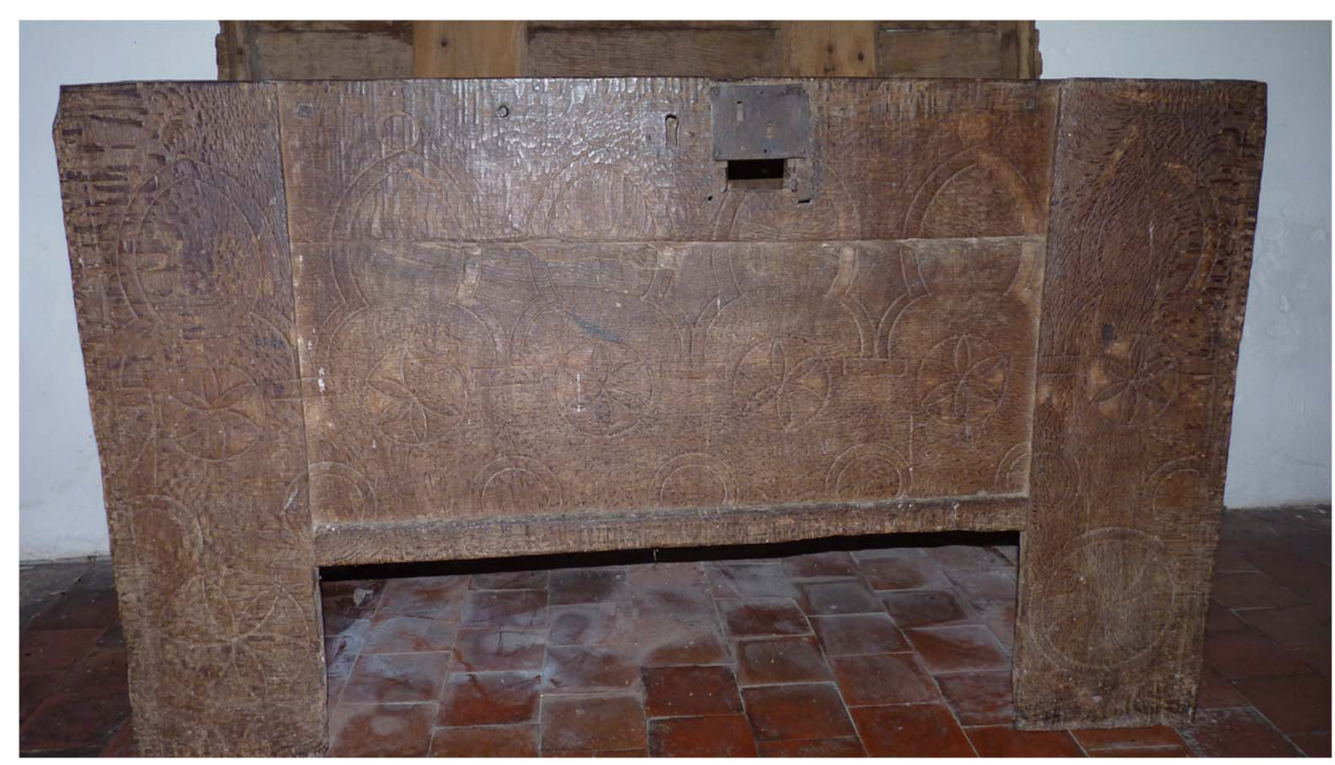

Fig 4. Wormshill chest. Photograph: author.

\section{THE LITERATURE}

The high point of scholarly interest in medieval chests was in the early twentieth century. In I902 Frederick Roe wrote the first book in England dedicated to the study of medieval 


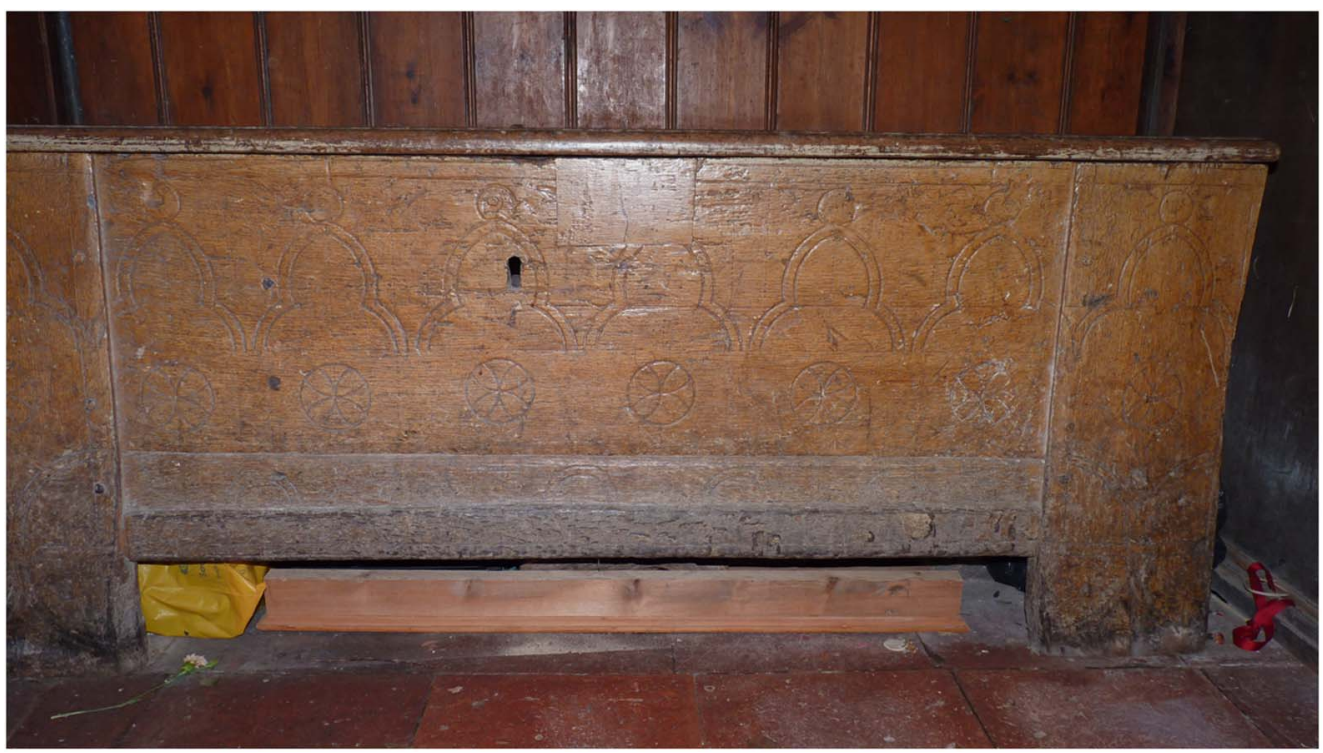

Fig 5. Norton chest. Photograph: author.

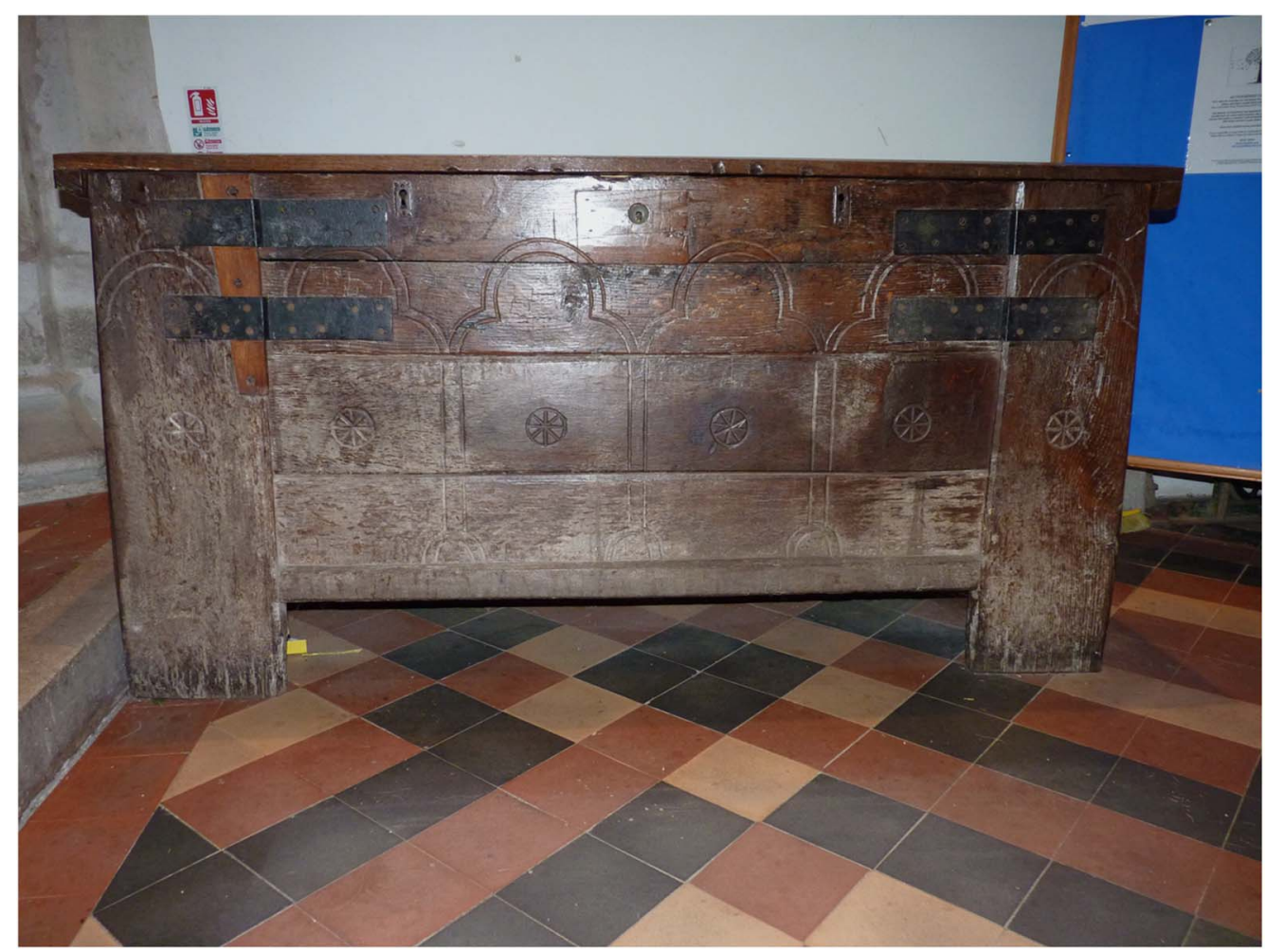

Fig 6. Boughton chest. Photograph: author. 


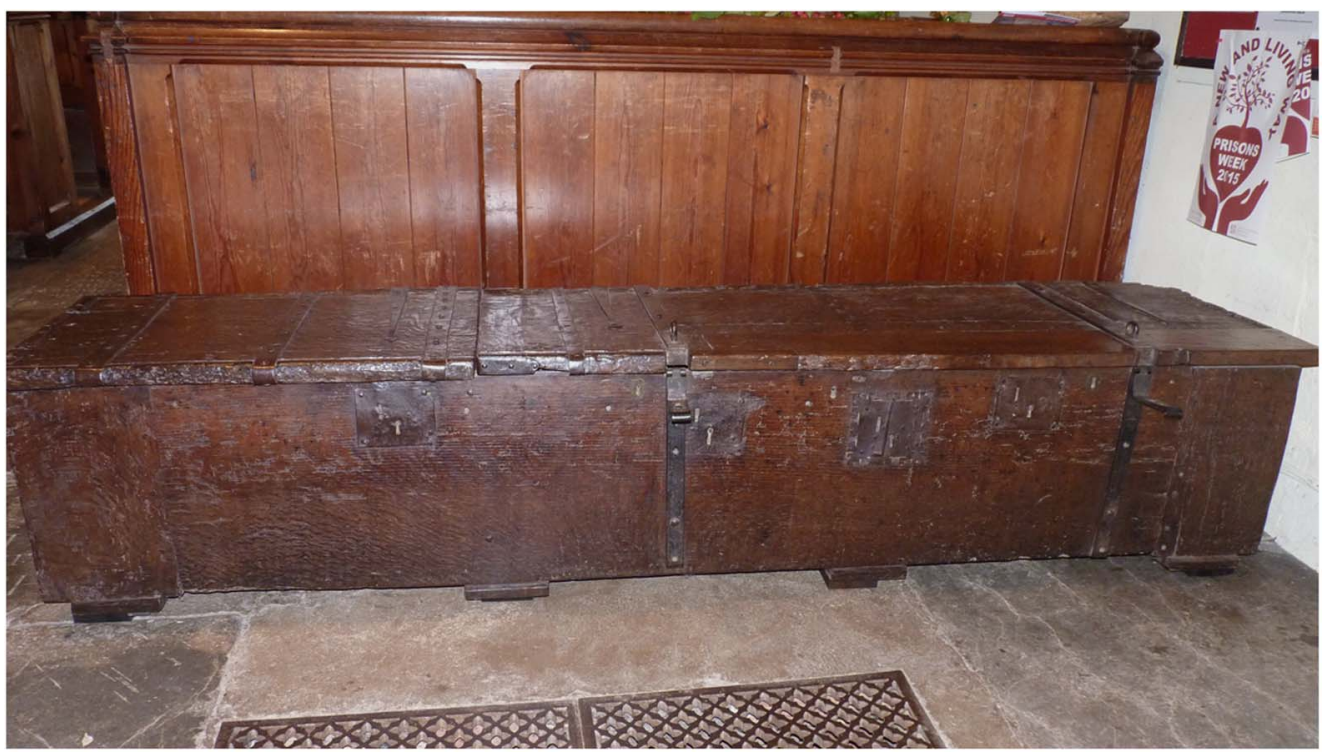

Fig 7. Yalding chest, after 2012 restoration. Photograph: author.

chests. ${ }^{3}$ Five years later, Philip Mainwaring Johnston wrote about what he considered to be twelfth- and thirteenth-century chests (especially on dug-out and pin-hinged, clamped chests). ${ }^{4}$ Johnston provided summary information on numerous early chests and detailed information on a smaller set. His conclusions about dates, hinges and lock types are discussed below. The first county survey was compiled in $1913 ;^{5}$ it contained a valuable study of historical documents on the uses of chests. ${ }^{6}$

Just after the First World War, Roe's History of Oak Furniture added new examples and Cescinsky and Gribble's major work on early English furniture and woodwork paid particular attention to who made furniture and to regional differences. ${ }^{7}$ In I929, Roe's last book surveyed chests in the Home Counties. ${ }^{8}$ Morgan's thorough survey of Herefordshire chests appeared in I947 and Jennings's study of Public Record Office chests in 1974. ${ }^{9}$ In I977, Eames published her major survey of English, French and Flemish medieval furniture, which included eighteen chests. ${ }^{\text {IO }}$ Geddes and Sherlock's article on two chests with scrolled ironwork appeared in 1987 and in 1999 Geddes published her major study of medieval decorative ironwork, which included numerous chests. ${ }^{\text {II }}$

Recently, there has been renewed scholarly interest in medieval chests, partly stimulated by the rise of dendrochronology. Sherlock's Suffolk Church Chests is a complete survey and

3. Roe I902.

4. Johnston 1907; pin hinges are explained below.

5. Lewer and Wall I9I3.

6. The term 'church chest' is discussed below.

7. Roe I920; Cescinsky and Gribble 1922.

8. Roe 1929.

9. Morgan 1947; Jennings I974.

Io. Eames 1977.

II. Geddes and Sherlock I987; Geddes I999. 
selects a number of examples for detailed study. ${ }^{\mathrm{I} 2}$ Two dendrochronologists have published studies of the Westminster Abbey chests and an overview of dendro-dated chests. ${ }^{\text {I3 }}$ Other recent studies have focused on early fifteenth-century, iron-bound, boarded chests with dug-out domed lids, and fourteenth- and fifteenth-century, tracery-carved, clamped chests. ${ }^{\text {I4 }}$ Outside England, Stülpnagel's systematic study of ninety-five thirteenth- and fourteenth-century chests in monasteries in Lüneberg Heath (Lower Saxony) set a new standard for research and also included a survey of chests in northern European museums and churches. ${ }^{15}$ The study of the Valère chests at Sion is of high quality as is the study of iron-bound Westphalian clamped chests, and the V\&A database contains extensive detail on individual chests. ${ }^{16}$

Despite these publications, knowledge of medieval chests is unsystematic. Construction type and decorative style have often been taken as indicators of age, leading to a lack of awareness of the continued use of simple construction types and 'outdated' decorative styles. The extent of replacement of ironwork, reuse of carved fragments, later carving, and importation of Continental chests has been underestimated, and present location has often been taken as an indication of place of production. ${ }^{17}$ The application of dendrochronology has significantly advanced the dating and provenancing of timber, but, as discussed below, it has limitations. All general statements about national types of chest and individual identifications must, therefore, be regarded as provisional. In the absence of funding for large-scale studies, the best way of building knowledge is by detailed studies of types of chest in particular areas. The present study seeks to contribute by identifying the features of a specific group of chests and making comparisons with related chests at home and abroad. ${ }^{\text {I8 }}$

Medieval chests found in churches are most likely to be used to store vestments, altar cloths, church plate, jewellery, legal documents, relics, books and money. ${ }^{19}$ There is a tradition that each altar had a chest to store its accoutrements. ${ }^{20}$ In parish churches in the thirteenth century, chancels were rebuilt or refurbished and nave aisles added to provide improved settings for the main altar and for chantry chapels with their altars. ${ }^{2 \mathrm{I}}$ The increased volume of valuable church furnishings such as vestments, altar frontals, liturgical equipment, crosses and images of the Virgin Mary led the Exeter synod of 1287 to create the role of churchwarden and require that churches provide chests for books and vestments ('cistam ad libros et vestimenta'). ${ }^{22}$ However, identifying what chest had what purposes is difficult as inventories are more likely to describe the contents of chests than the chests themselves.

I2. Sherlock 2008.

I3. Miles and Bridge 2008; Bridge and Miles 2011.

I4. Simpson 2008; Sherlock 20II; Pickvance 2012, 2014, 2015, $2017 \mathrm{a}$.

I5. Stülpnagel 2000.

I6. Baumeier 20I2; Charles and Veuillet 20I2; http://collections.vam.ac.uk/ (accessed I8 Jul 20I8).

I7. Eames 1977; Tracy 200I; Pickvance 2007, 2012, 2014, 2015.

I8. Since conducting the research on the arcaded gothic group, the author has gone on to research pin-hinged, clamped chests in Sussex, Surrey and elsewhere, and has referred to this research here in places.

19. Eames 1977, 108-37.

20. Lewer and Wall I9I3, 48; Howard and Crossley I927, 342.

2I. Draper 2006, 40, 50-I, I98-200.

22. Binski 2004, I76. 


\section{THE ARCADED GOTHIC GROUP OF CHESTS}

None of the chests under discussion has a documented provenance before the nineteenth century, but all could have been commissioned for the churches and almshouse in which they survive. ${ }^{23}$ Of the six chests, the Graveney chest has received most attention in the literature. In 1902, Roe wrote: 'There are probably no older coffers bearing any pretence to decorative carving remaining in the kingdom other than those in the churches of Graveney, Kent, Climping, Sussex and Stoke d'Abernon, Surrey. ${ }^{, 24}$ A trained artist, Roe included a drawing of the Graveney chest in his book, ${ }^{25}$ noted its Early English arches and dated the three chests to the mid-thirteenth century. Johnston's 1907 work includes the Graveney chest, ${ }^{26}$ which he dates to I200-20, but omits the other five arcaded gothic chests, which suggests that they were then unknown. ${ }^{27}$ Shortly after, Cox and Harvey listed the chest at Graveney ('I3th century') in their book on 'church furniture'. ${ }^{28}$

In 1915, a brief note in The Antiquary reported a 'thirteenth century chest, which appears to have escaped the notice of all previous writers' at Wormshill and which 'is very similar to the thirteenth century chest at Graveney in the same county, but certainly a better specimen'. ${ }^{29}$ In a I9I 8 article, Roe for the first time drew attention to the two St John's Hospital chests, which he described as 'of thirteenth century origin'; he gave a brief description, but did not include illustrations. ${ }^{30}$ In his 1920 book, Roe refers to the Graveney chest with its 'pointed and cusped arches of the ... Early English style'. ${ }^{3 \mathrm{I}}$

The arcaded gothic group did not appear in Cescinsky and Gribble's 1922 book or in the Dictionary of English Furniture (I954). ${ }^{32}$ The Wormshill chest appeared in a 1954 book on Kent churches along with brief notes and was described as thirteenth-century, 'contemporary with Graveney'. ${ }^{33}$ In 1957, according to an article by Grove, this chest was exhibited at St Augustine's College, Canterbury, having been 'coaxed' 'from the obscure remoteness of St Giles church' by Mr Michael Nightingale. ${ }^{34}$ The article contained a photo and detailed description and a footnote reference to the Norton chest. Grove was the first to

23. Wormshill church is Saxon, Graveney and Norton churches are Norman, Boughton is early thirteenth century. However, there are no records of the arrival of their chests (Newman 2002). For St John's Hospital (an almshouse founded by Archbishop Lanfranc in the late eleventh century), an inventory from 1546 records three chests in the hospital chapel, but does not describe them (Holland I934, I8-I9.) The preceding list of 'movable goods' suggests the chests were used to store church plate, altar and other cloths, a latten cross and censor, and Mass books. (The author wishes to thank Sheila Sweetinburgh for this reference.) Duncombe and Battely's study of St John's Hospital refers to 'a strong chest' where 'the ancient charters, etc. are deposited' (but is unspecific about it) and a 'coffer with three several keys and locks' used to store money in St John's 'hall' (today called the refectory), which does not match either chest $A$ or $B$ (I785, I93 and 217). However, chest $B$ is known to have been brought into the refectory from a 'damp tool shed' next to the chapel around I9I6 (Roe I918, 79).

24. Roe 1902, 20.

25. Ibid.

26. Johnston 1907.

27. Ibid.

28. Cox and Harvey 1908, 303.

29. Underhill I915, 42-3.

30. Roe I9I8, 78 .

31. Roe 1920, 4.

32. Cescinsky and Gribble I922; Macquoid and Edwards I954.

33. Boorman and Tarr 1954, I44.

34. Grove 1958, 215. 


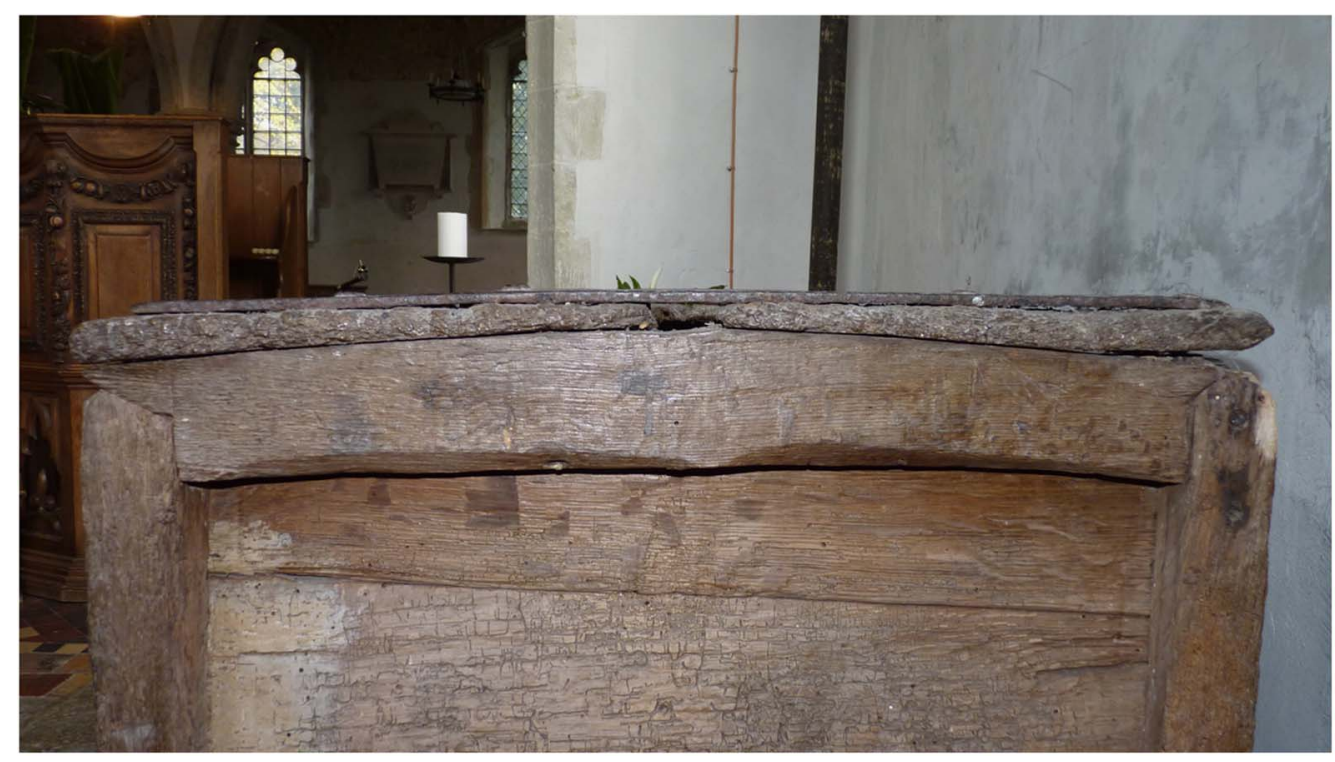

Fig 8. Side view of lid showing shaping of lid boards, cleat chamfers and shadow from protective plate over iron rod, Graveney. Photograph: author.

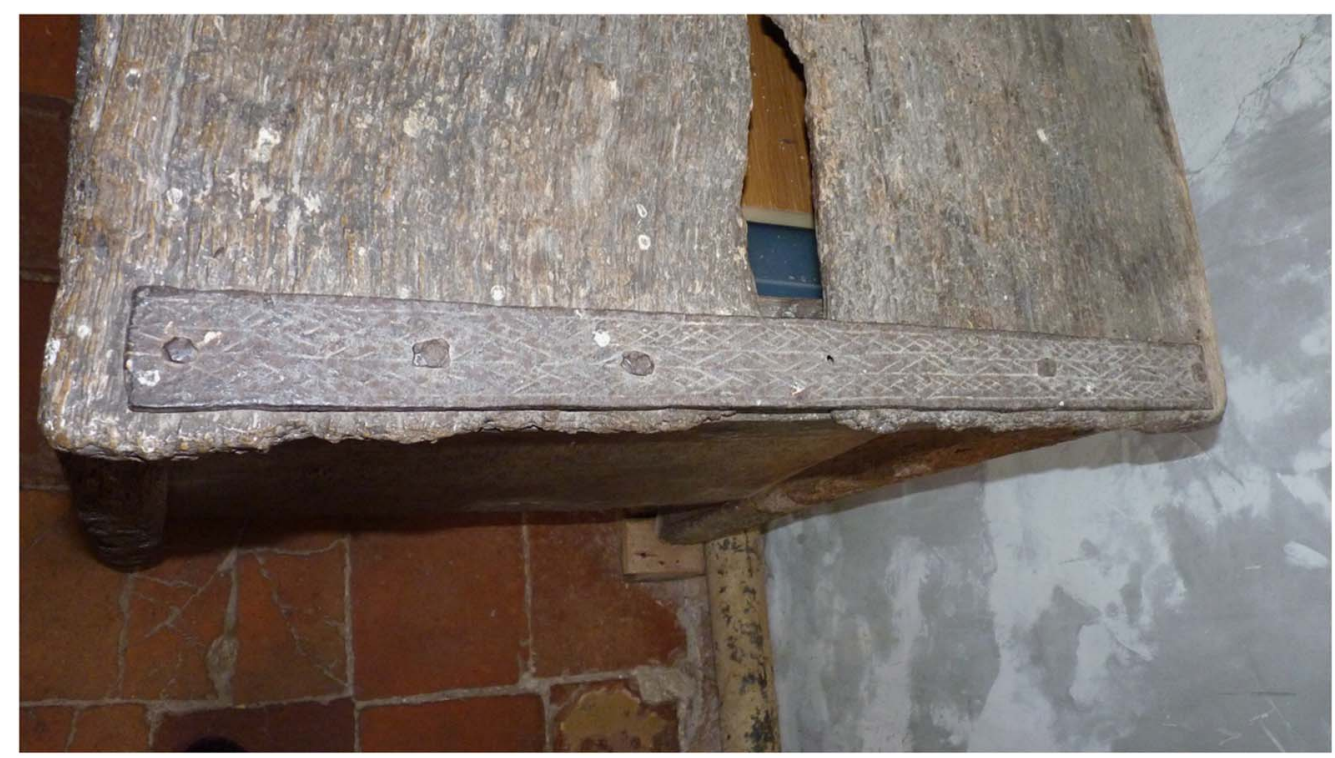

Fig 9. Cross-hatched iron strap on lid, Graveney. Photograph: author.

propose that the Graveney, Wormshill and Norton chests constituted a group, but appears not to have been aware of the St John's Hospital chests. ${ }^{35}$ The Graveney chest did not appear in Eames's 1977 study, though she does include the Climping chest. ${ }^{36}$ The Graveney

35. Ibid, 214 .

36. Eames $1977,143-5$. 


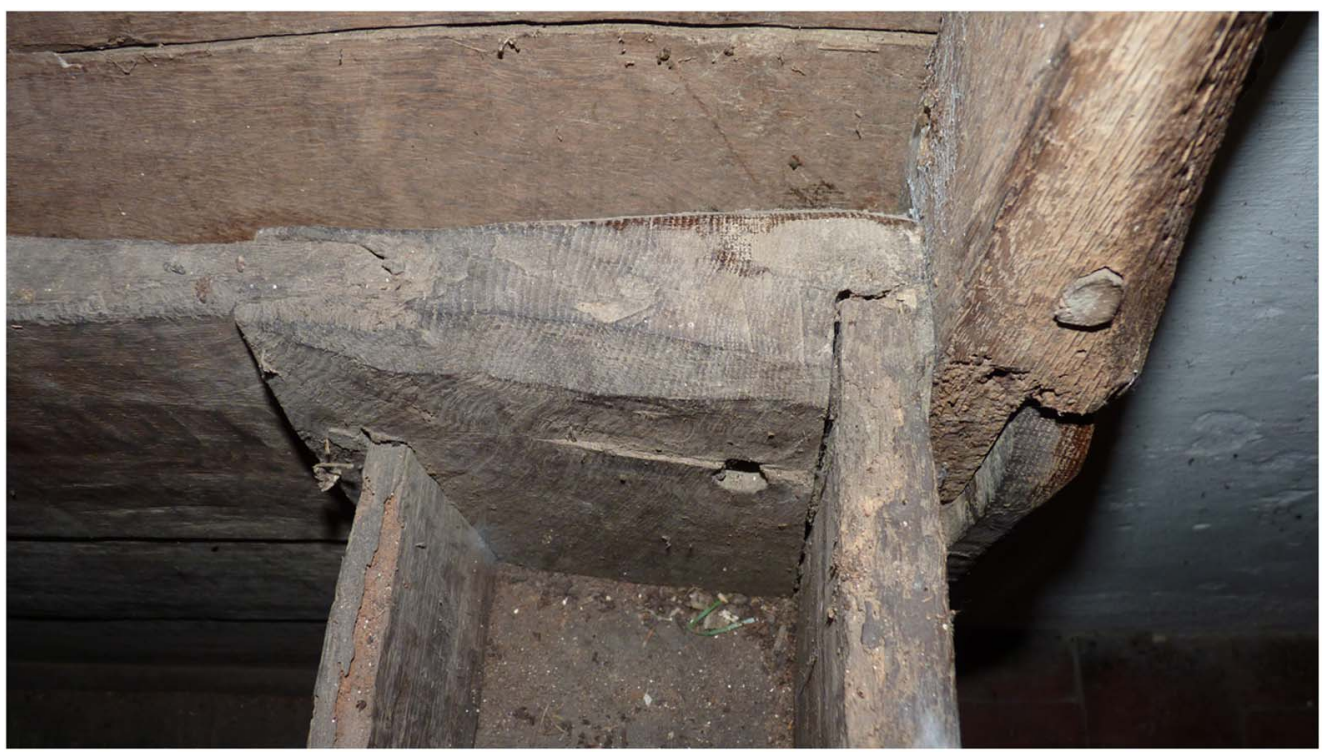

Fig Io. Pin hinge (and till box) seen from inside, Wormshill. Photograph: author.

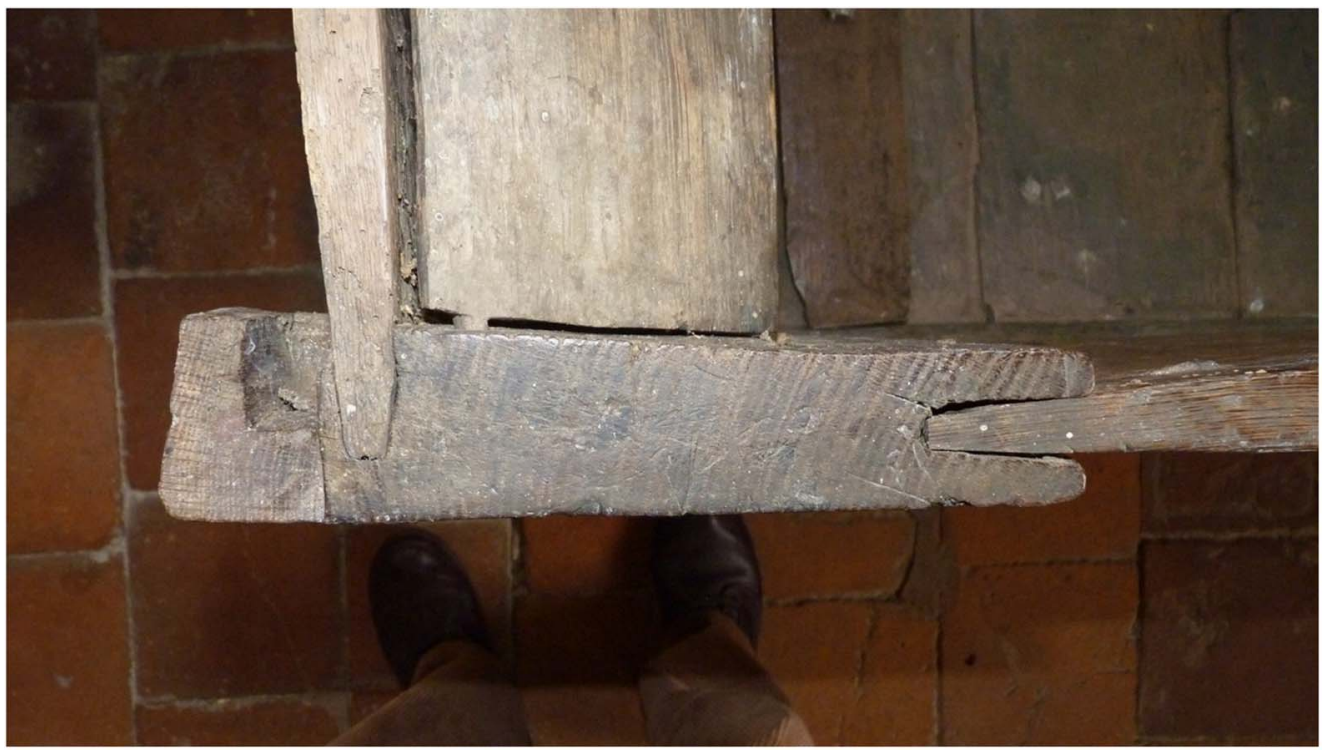

Fig II. View showing tapered stile, notch for cleat and tapered tenons (and till box lid), Graveney. Photograph: author.

chest was used as an example of clamped construction by Chinnery in 1979, who considered it to be thirteenth-century. The Boughton chest has not been previously recorded and was identified by the author in 2017. 


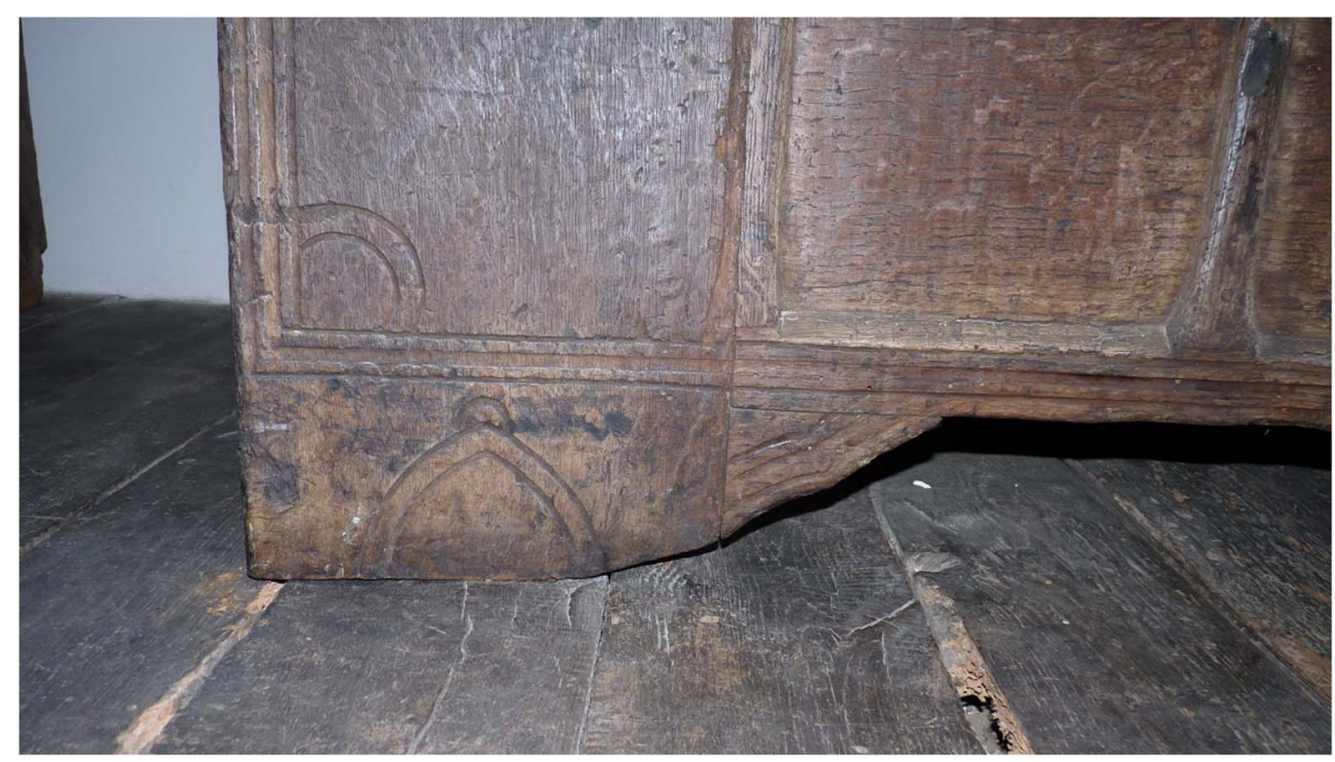

Fig I2. Spandrel and scratchstock moulding, St John's B. Photograph: author.

DESCRIPTION OF THE SIX CHESTS

\section{Overview}

Dimensions Apart from the smaller Norton chest, all the chests are around $150 \mathrm{~cm}$ wide $\times$ $85 \mathrm{~cm}$ high (original height of the space below the front $25 \mathrm{~cm}$ ) $\times 70 \mathrm{~cm}$ deep. They are notable for their internal height and depth.

Lid Four chests have original lids. They are made of two (Graveney; St John's $A$ ) or three (St John's $B$; Wormshill) long butt-jointed boards, which are dowelled together and pegged to cleats (or battens or rails) beneath each side. ${ }^{37}$ The front and rear boards are tapered in cross-section, ranging from $2 \mathrm{~cm}(\max )$ at the front and back to $1.3 \mathrm{~cm}$ at the centre; the middle board is thinner and untapered (fig 8). The tapering is the result of converting timber by cleaving or riving, ie splitting along the grain. Compared with sawing, riving preserves the strength of the wood and is less likely to lead to warping. ${ }^{38}$ The Graveney lid is unique in having two iron reinforcing straps with engraved decoration; the cross-hatched right-hand one may be re-used (fig 9).

The upper edge of each cleat is slightly rounded from front to rear, which matches the tapering of the lid boards and means that the lid has a flat upper surface. The outer edge of each cleat has two (St John's $A$, Graveney, Wormshill) or three (St John's $B$ ) stopped chamfers (see fig 8). The cleat is wedge-shaped in cross-section. Its rear end forms part of the pin, or pivot, hinge (fig Io). The outer side of the front end is cut at an angle to match the

37. Where a chest has lost an original feature, such as a lid, it is omitted from the corresponding discussion. For modifications to the chests, see Appendix SMI in the Supplementary Material.

38. Simpson and Litton 1996. 


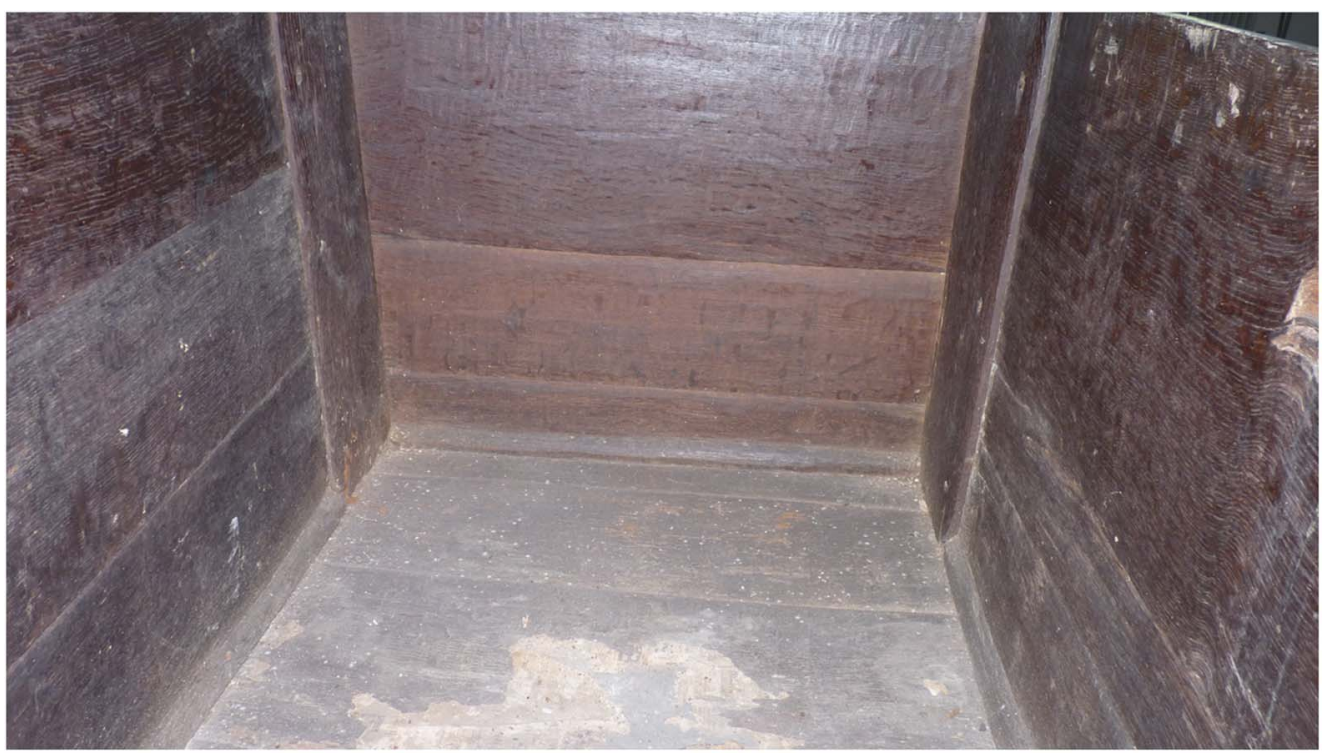

Fig I3. Internal view showing smooth surfaces with quarter-round lip, St John's $A$.

Photograph: author.

angled face on the outer top of the stile; the (slightly wedge-shaped) tenon projects from the inner side of the front of the cleat and sits in a notch in the front stile.

Stiles The stiles (uprights) are the main structural timbers and range from $20-28 \mathrm{~cm}$ in width at the front and the same or less at the rear. These provide mortises into which the wide tenons of the front, back and side boards are pegged, and notches to house the tenons on the lid cleats. The stiles are shaped in two dimensions: first, they taper from outside to inside - typically from about $5 \mathrm{~cm}$ to about $3 \mathrm{~cm}$ (fig II); ${ }^{39}$ second, except at Norton, the 'feet' of the stiles are tapered when seen from the side. The St John's, Boughton and Wormshill chests originally had spandrels (filling the corners between front feet and lower front board); on the St John's $B$ chest, one carved spandrel remains (fig I2). Finally, the Graveney, Wormshill and St John's $B$ chests all have one stile with a very large knot, and the Boughton chest has two such stiles - this may be a cost-saving measure or reflect the unavailability of the best quality timber.

Bottom All six chests have a bottom constructed of boards of varying widths, aligned front to back, held in grooves in the four walls and the four stiles. The boards themselves are laterally 'V-jointed'; a V-shaped edge fits into a V-shaped groove on the adjacent board. This allows for some movement of the wood across the grain. The bottom boards are intact in all six chests, a tribute to the construction technique. In contrast, the fixing of bottom boards on seventeenth-century chests usually involves some nailing. At St John's $A$ alone, there is a stout supporting batten running side to side beneath the bottom that appears to be original.

Front, sides and back The façade is slightly recessed: the top front board is about $2.5 \mathrm{~cm}$ thick, so there is a shallow 'step' (rounded on St John's $A$ ) between stiles and front boards. The front, sides and back consist of two horizontal boards (three at St John's $A$ )

39. The detail of the joint varies: it can show the tapered tenon, as here, or conceal it partially or completely, as in haunched or blind tenon joints. 


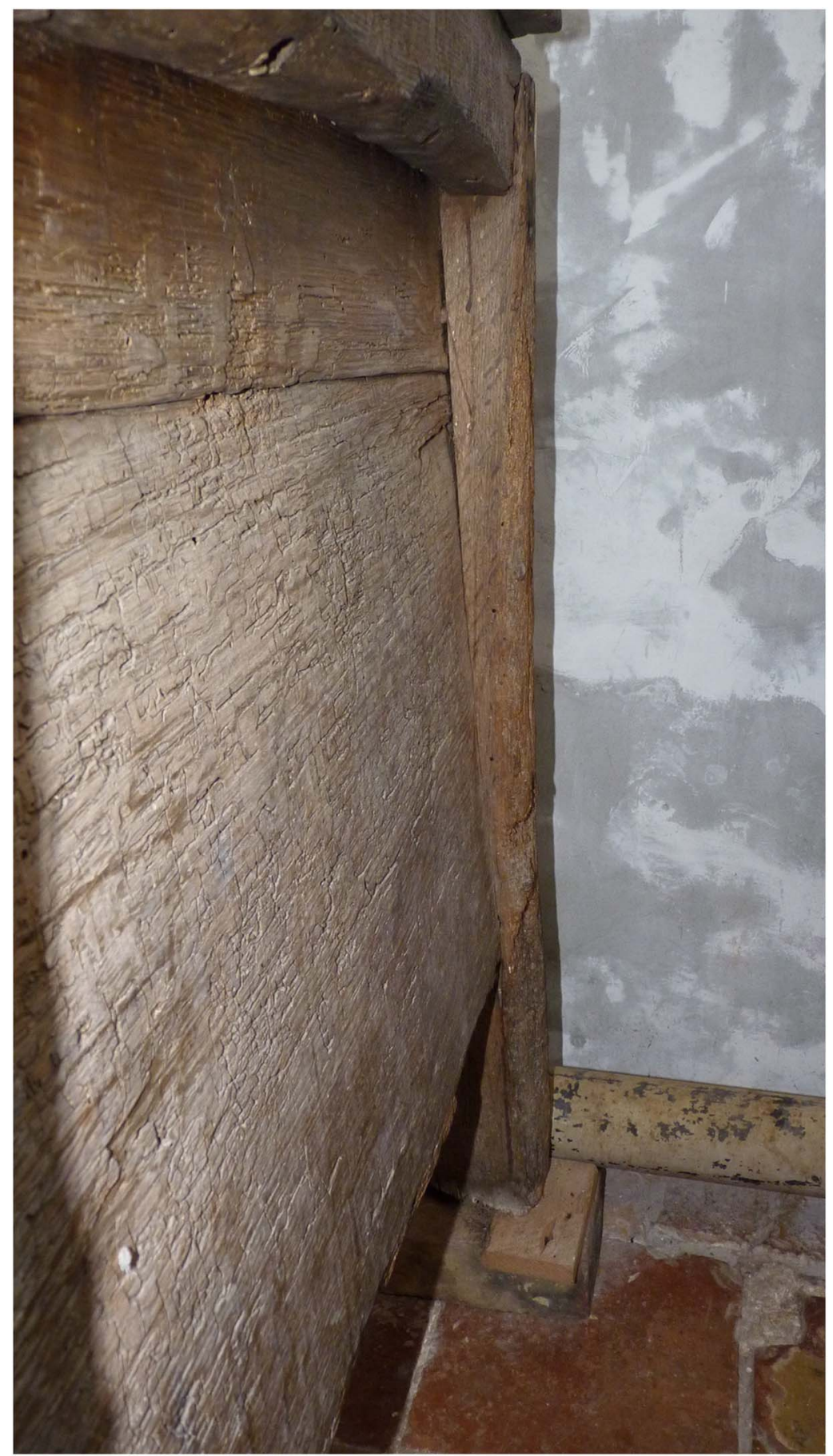

Fig I4. Inward-sloping sides allowing space for lid cleat within width of chest, Graveney. Photograph: author. 


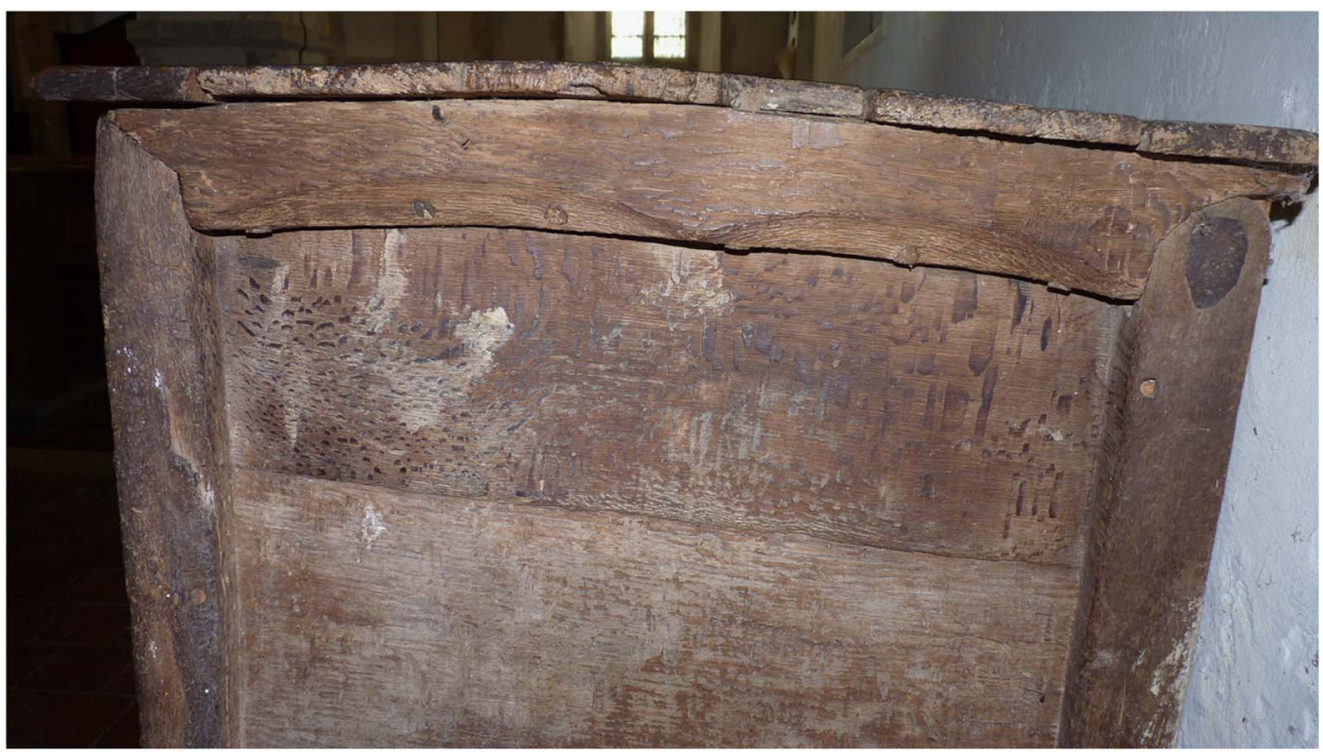

Fig 15. Protective plate over pin hinge and chamfered cleat, Wormshill. Photograph: author.

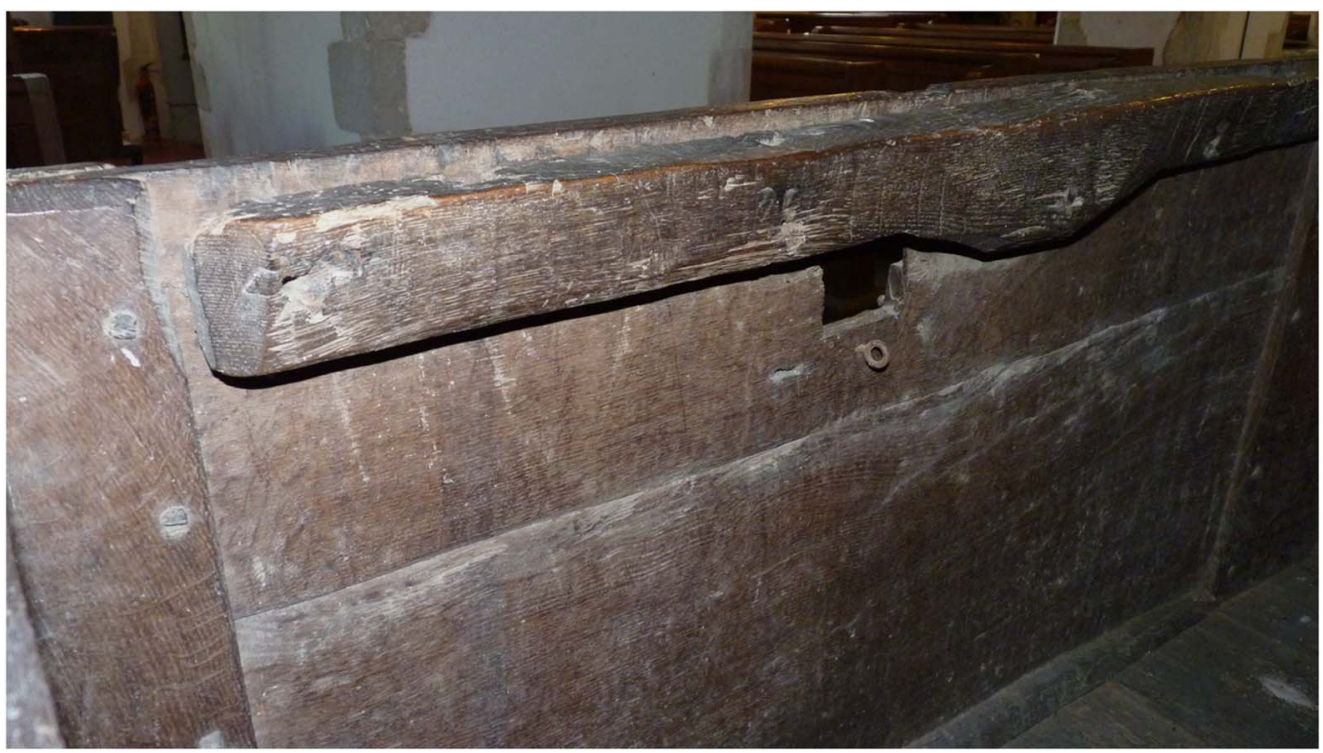

Fig I6. Wooden sliding bolt cover, quarter-round lip above bottom boards, Wormshill. Photograph: author.

which are V-jointed together and held in the stiles by three (four at Graveney) pegs. The width of the boards is often not constant, creating a trapezoid shape (see fig 3 ); assuming the timber is supplied with a taper in its width, this would save on cost. Whereas the upper 


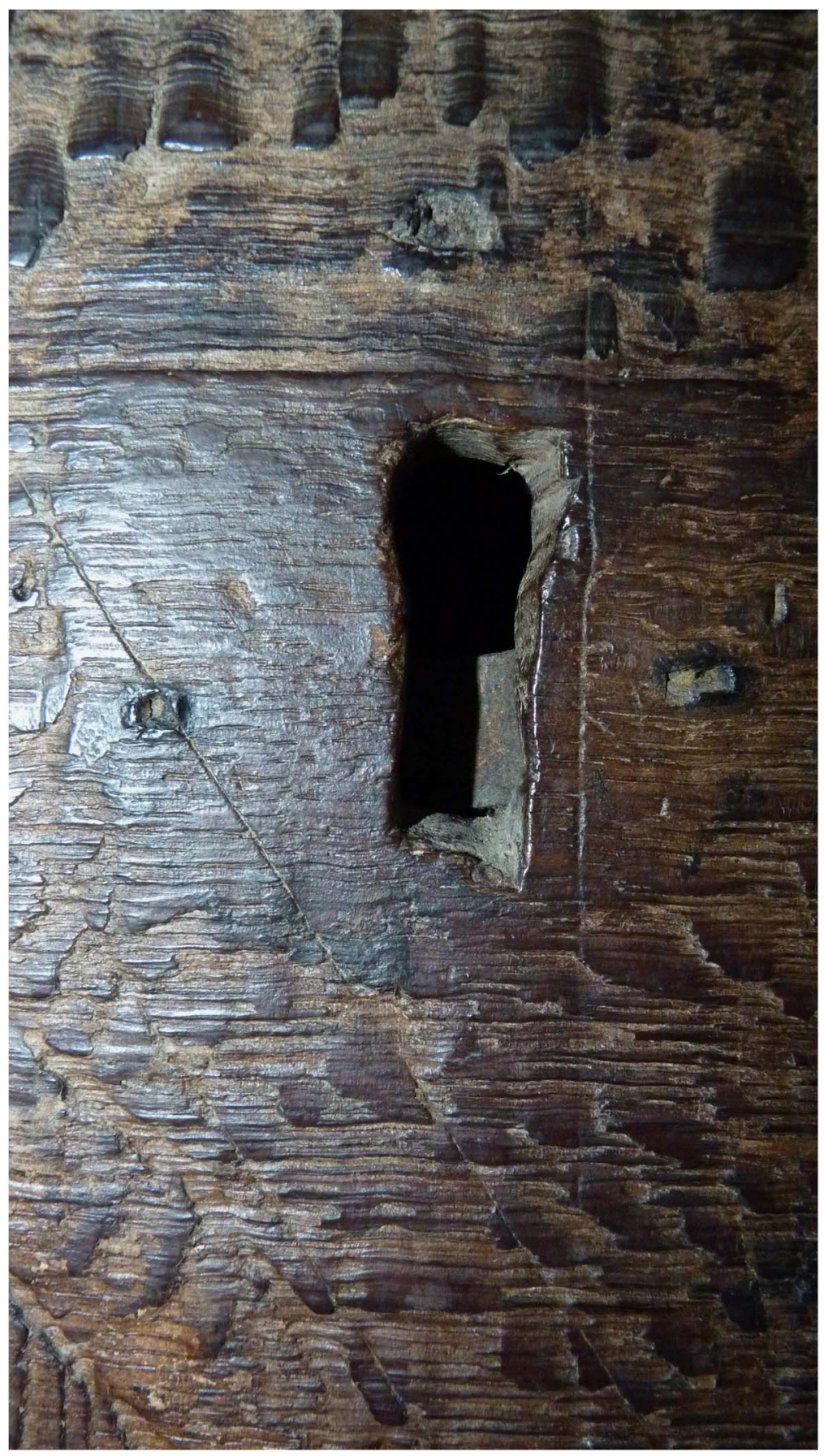

Fig 17. Circular escutcheon shadow, three nail holes, Wormshill. Photograph: author. 


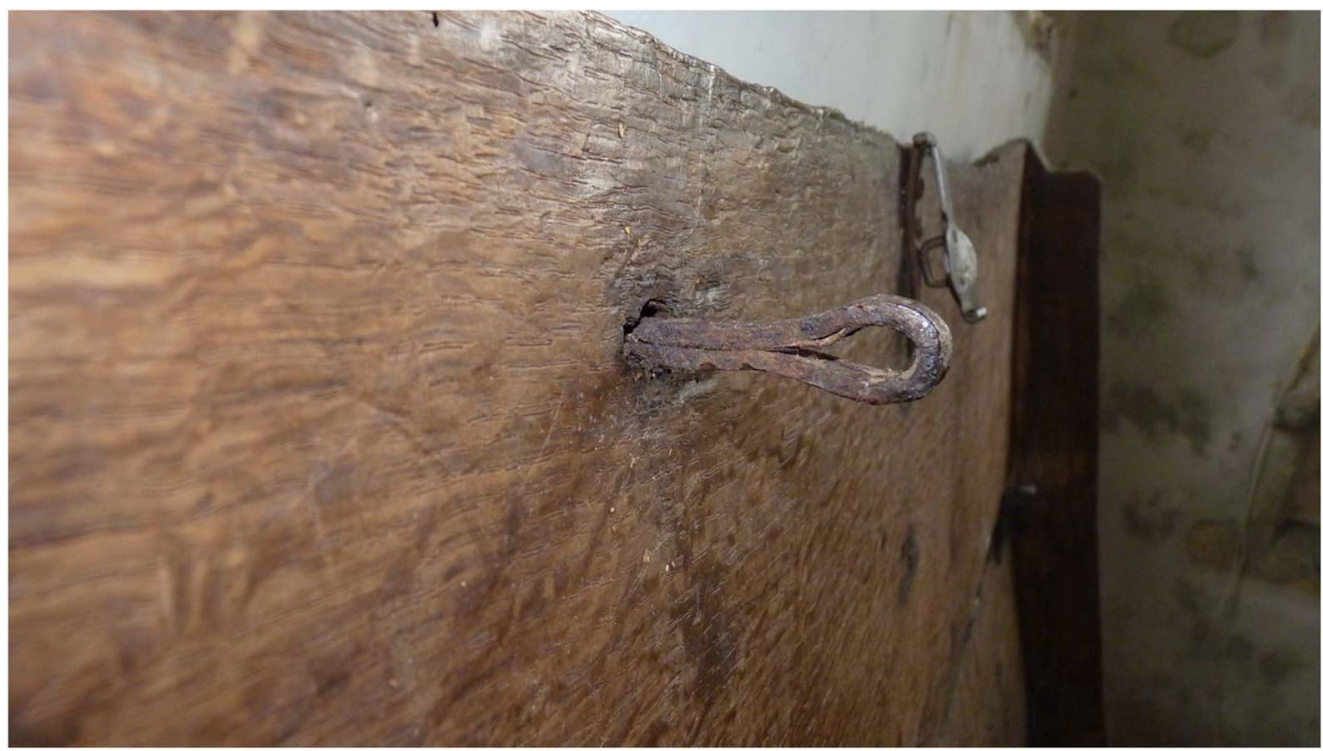

Fig I8. One (of two) original staples underneath lid, Graveney. Photograph: author.



Fig I9. Iron fixing bolt with projecting head with disc, St John's B. Photograph: author.

boards are of constant thickness $(2-2.5 \mathrm{~cm})$, the lower boards start at this thickness at the $\mathrm{V}$-joint and widen to $4-5 \mathrm{~cm}$ at their bottom edge. These boards are shaped in two ways. The lower front board is shaped externally to produce the canted edge close to the bottom 


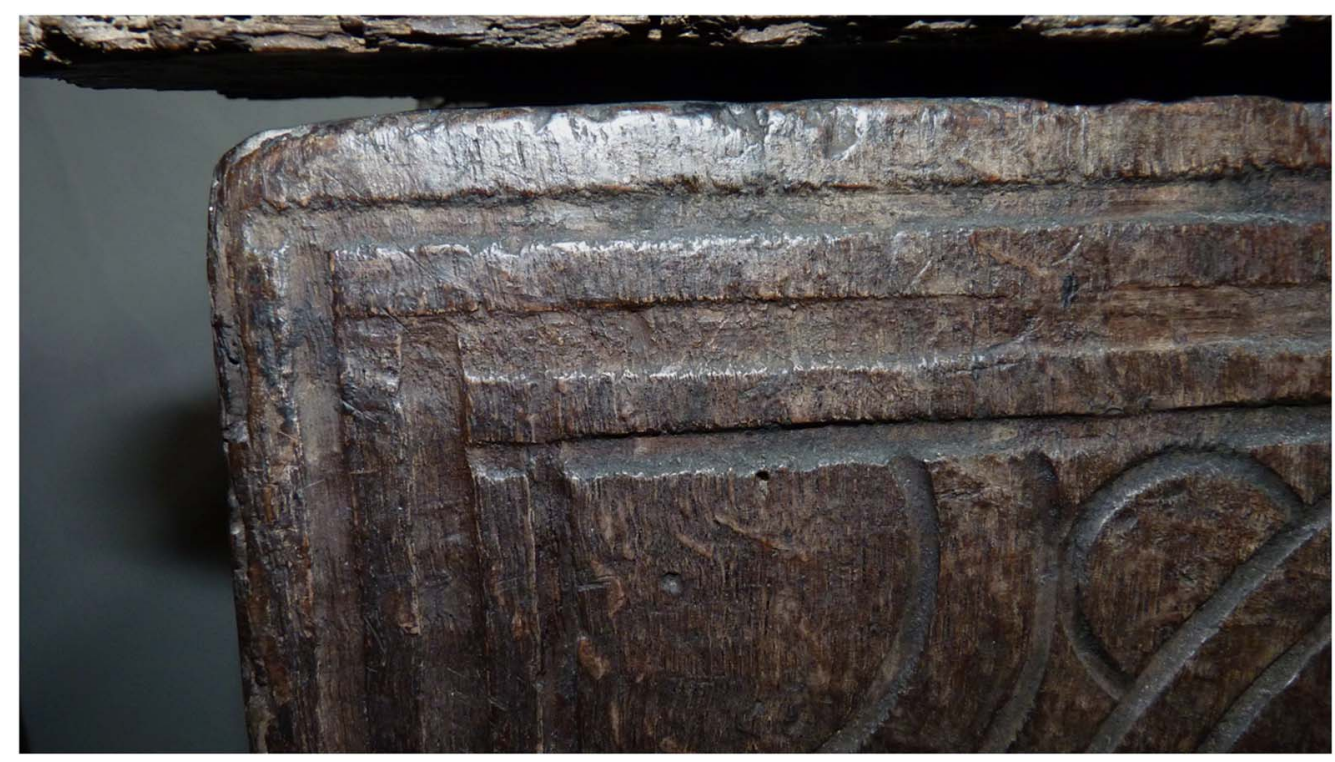

Fig 20. Triple scratchstock moulding on façade, St John's B. Photograph: author.

(see figs I-6)..$^{40}$ Internally, the lower boards of the front, back and sides have a 'lip', which at first sight looks like a quarter-round applied moulding but is cut in the solid (fig I3). The lower boards thicken out at the bottom to provide depth for the groove for the bottom boards. All the chests originally had a single-tier 'till box' for small objects; it is completely missing only at Norton. The sides of all the chests slope inwards to allow the lid cleats to sit within the overall width of the chest (fig I4). The inside surfaces of all the chests are very smooth as the uneven riven surface has been adzed and planed (see fig I3). In contrast, the undersides of the bottom boards are left rough.

Hinges All the chests originally had pin hinges. Today they are only intact on the Graveney and Wormshill chests. The pin hinge is simple in concept. The cleat attached under each side of the lid has a hole at the rear end and rotates on an iron rod fixed across a notch in the rear stile. A kite-shaped iron plate held on by three nails was usually fixed over the end of the rod to afford some protection against forced removal. These plates are intact only at Wormshill (fig I5).

Locks Most medieval chests have had a series of locks. It is, therefore, essential to reconstruct the sequence of locks on a chest to distinguish between original and later locks. This is often a matter of judgement since many types of lock were in use for long periods and overlapped with each other, and previous locks may only be evident from the four holes for the lock plate. ${ }^{4 \mathrm{I}}$ None of the four arcaded gothic chests with intact upper façade boards has ever had three locks. A close examination reveals that they all originally had single locks with a sliding bolt with two 'prongs' contained within a wooden cover fixed to the rear of the

40. At Graveney, the canted edge is missing, but this is due, the author believes, to the relevant part of the lower board having split off. Grove $(1958,215)$ suggests that the bottom of the chest protrudes beyond the lowest board of the front edge. In fact, what is visible is a later (but old) batten, added presumably after the grooved bottom edge of the lower front board split off; this batten now helps to support the bottom boards.

4I. For lock types and their dates, see Chinnery 1979, I44. 




Fig 2I. Whorl showing alternate colour in rays, Wormshill. Photograph: author.

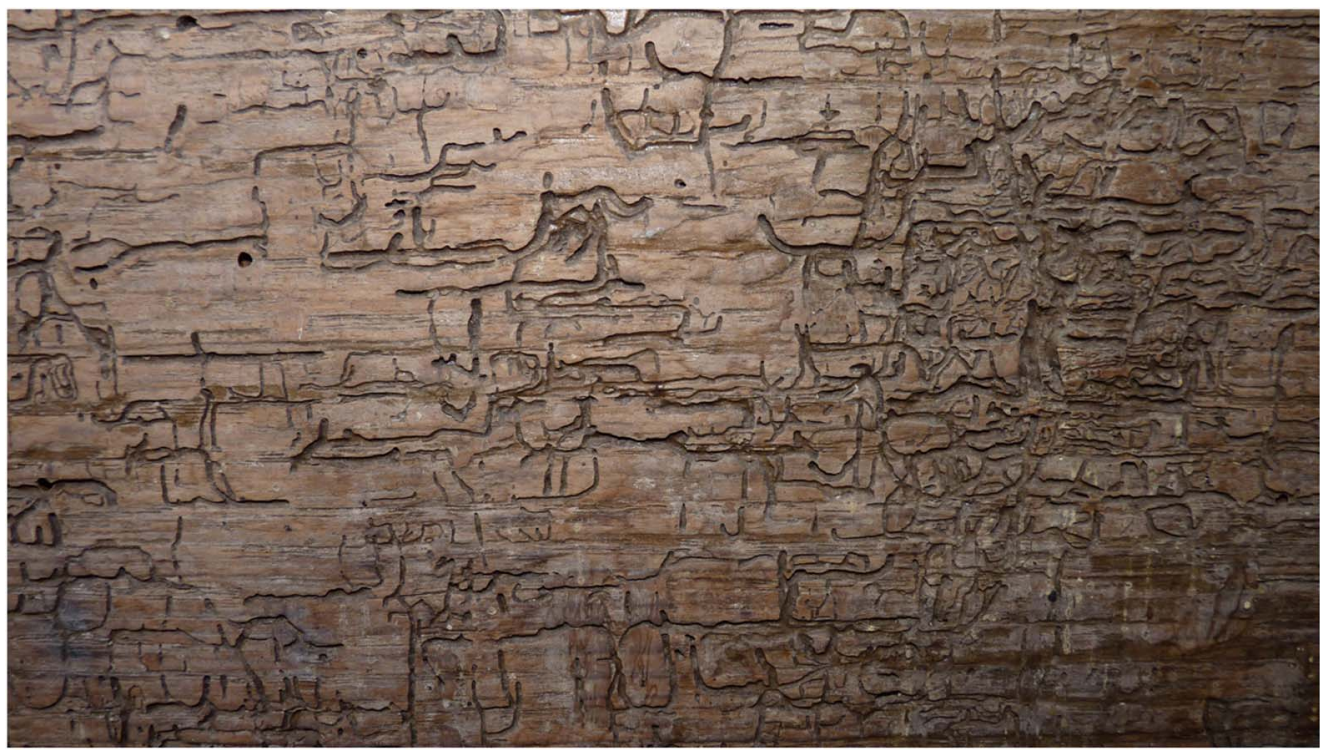

Fig 22. Open worm tracks, right-hand side, Graveney. Photograph: author.

upper façade board. ${ }^{42}$ At Wormshill this cover is extant; it is $5 \mathrm{~cm}$ thick, $6 \mathrm{~cm}$ high in the middle tapering to $3 \mathrm{~cm}$ at each end (fig $\mathrm{I} 6$ ). The Wormshill chest shows a circular, unscrubbed area with three small holes around the keyhole, which suggests that the original escutcheon was circular and nailed on (fig I7). Staples fixed to the lid fit into slots in the

42. Their subsequent locks are mentioned in Appendix SMI in the Supplementary Material. 


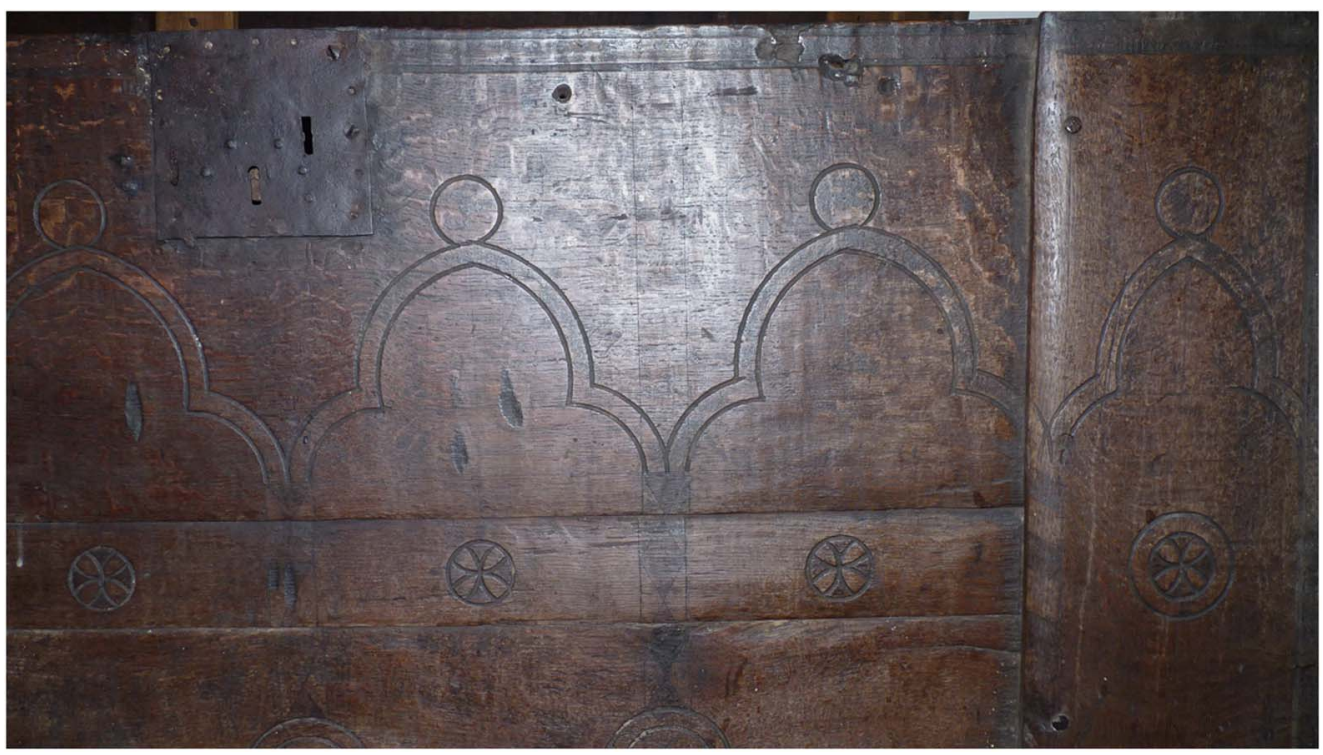

Fig 23. Roundels with cross pattées, lozenges, contrasting stripes and scribe lines, St John's $A$. Photograph: author.

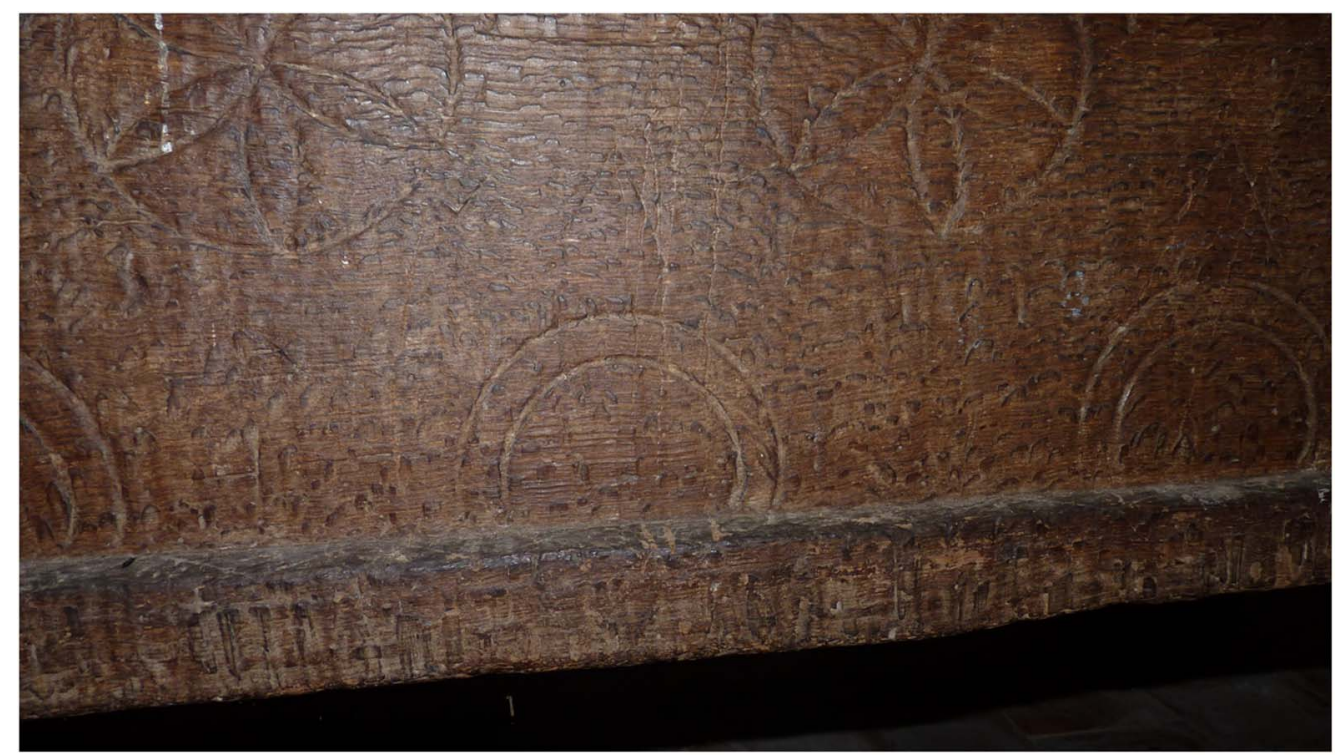

Fig 24. Chevrons on the canted edge, Wormshill. Photograph: author.

wooden cover. When the key is turned, it moves the bolt and the bolt prongs engage with the staples. In none of the chests is the sliding bolt itself extant; a radiograph at Wormshill revealed that the bolt had been removed. The three chest lids that are complete (Graveney, 


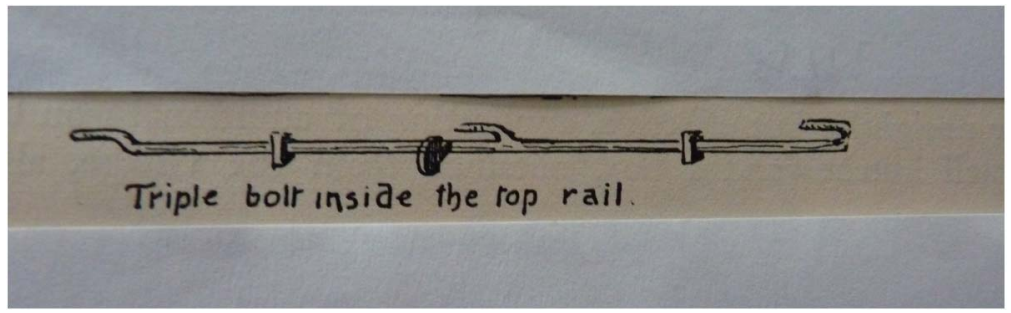

Fig 25. Sliding bolt, St Mary's church, Hatfield Broadoak. Source: Lewer and Wall I9I3.

St John's $A$ and $B$ ) have two holes where the iron staples were fixed through the front board; these are 55, 66 and $56 \mathrm{~cm}$ apart. ${ }^{43}$ At Graveney one staple survives with its split ends protruding through the lid, and the remains of a nail nearby suggest that the ends were covered by a small iron plate (fig I 8 ). The chests where the façade is intact had a row of four iron bolts close to the upper edge, which held on the wooden bolt cover; on the St John's $B$ chest, one bolt survives with a projecting square head and circular washer or disc (fig I9) and on the other chests the stains or depressions from these discs can be seen. ${ }^{44} \mathrm{At}$ Wormshill the splayed ends of the fixing bolts can be seen. At St John's $A$ the bolt holes are in line, whereas at St John's $B$, Graveney and Wormshill the two middle holes are lower (see figs I-4); this difference may be due to different shapes of wooden cover.

Sliding bolt locks are likely to have been more complex to install than hasp locks since the prongs, bolt cover and lid staples all have to be precisely aligned for them to work; for this reason, sliding bolt locks are likely to have been a costly option. However, their rare survival suggests that they had several weaknesses. As well as misalignment (for example, due to bent staples or failing pin hinges), the staples could be removed from the lid by levering off the protective plates and excavating the ends, or the lid could be levered open, breaking off the front of the lid and/or the upper part of the façade with the sliding bolt, leading to replaced boards or whole lids, as can be seen at Boughton, Norton and Wormshill.

\section{Decoration}

Arcaded decoration The most striking decorative feature of the six chests is the gothic arcading, which is incised on five chests and grounded with applied columns or mullions on the St John's $B$ chest. The number of arches varies from five to eight. Except for St John's $B$ and at Graveney, this is combined with roundels of different sizes and designs.

The decorative features of the façades are as follows:

- A rectangular double or (at St John's $B$ ) triple frame extends over the whole façade, except at Wormshill where the lower horizontal is absent and at Boughton where there was probably no frame (fig 20). The shallow, flat, moulded framing at St John's

43. On the St John's chest lids, the holes are roughly in line; on the Graveney chest, the holes are $2 \mathrm{~cm}$ out of line. This difference may relate to the design of the bolt. If the front end of the bolt is cranked and the rear end bent into a ' $U$ ' shape, the two 'prongs' and the corresponding positions of the staples would be in line. If the front end is not cranked, the prongs (and staple positions) will not be aligned.

44. Owing to the state of the iron, one cannot distinguish between a loose washer and an attached disc. 
$A$ and $B$ is superior in quality to the incised framing at Graveney, Norton and Wormshill, but both types are probably made with a scratchstock - a hand-cut metal blade fixed in a wooden handle and drawn along the edge of the timber. ${ }^{45}$ The $\mathrm{St}$ John's $A$ till box lid has the same double scratchstock moulding along each side.

- Except for St John's $B$, all the arcading is incised with a double line and shows trefoil heads, columns and bases. On St John's $B$, all the stiles have doubly incised arches, but the three central arches are grounded and have applied columns. Except at Graveney, there are small blank circles above each arch (one at St John's $A$, Boughton, Norton and Wormshill; eight at St John's B). These may symbolise crockets. The main incised pattern was probably produced by a V-ended tool.

- Within the arches there are additional incised motifs: single or double roundels with cross pattées at St John's $A$, quatrefoil roundels at Norton, sixfoil roundels at Wormshill and roundels with eight segments at Boughton.

- In the lower corners of the frame, there are double quadrants at Graveney, St John's $A$ and $B$, and a pair of double quadrants at Norton and Wormshill.

- Except at Graveney and Boughton, on the 'feet' of each stile below the frame there are further incised motifs: double quadrants at St John's $A$ and Norton, a trefoil arch head at St John's $B$, and at Wormshill a large sixfoil roundel on the left foot and a large roundel with a whorl on the right (fig $2 \mathrm{I}) .{ }^{46}$

Paintwork It is hard to be certain of the previous surface finishes on early chests. Eames has argued that paintwork on medieval furniture either means painted decoration (such as the coats of arms on the de Bury chest) or the addition of colour to carved ornament. ${ }^{47}$ This would imply that where all-over paint is found, it is not original. Mercer, however, argues that the single colour or simple patterned painting of walls extended to early furniture. ${ }^{48}$ When wood has been painted, varnished or otherwise covered, it is common to find evidence of furniture beetle infestation in the form of open 'worm tracks' when the paint or covering layer is removed, but this can also be due to erosion or abrasion of the surface (fig 22). When open worm tracks are themselves painted, it is likely that the paint is not original. Also, it is not always possible to distinguish paint from stain since when paint is rubbed off it may leave a stain.

The clearest examples of colour on the arcaded gothic chests are on the St John's chests, where the contrasting dark and light diagonal stripes on the edges of the columns supporting the arches were presumably of different colours; the stripes are broad (chest $A$ ) and narrow (chest $B$ ) and their position is marked by scribe lines (fig 23). At St John's $A$, there are also dark and light lozenges within the three central columns of the arches, and dark and light areas within the roundels with cross pattées. ${ }^{49}$ It is also likely that the rectangular incised frame on the façade of five of the chests and the double lines of the arcades and columns were originally picked out in colour, as proposed for the scratchstock moulding on

45. Hewitt I980, 319.

46. Close examination reveals lightly incised scribe lines to lay out the arcaded design and to indicate the position of shading, stain or colour (see below). At Norton these are even visible through the overpainting. They were probably produced by a fine-bladed marking knife. One assumes that they were not intended to be seen. The double gables above each arch at Wormshill are not symmetrical and cannot have been used to lay out the design.

47. Eames I977, 231.

48. Mercer $1969,42-6$. This is supported by inventory descriptions of chests by their colour. There is also evidence of all-over stain or paint, as on the imported German red, domed, iron-bound chests (Pickvance 2012, 2015).

49. These lozenges can also be seen on the Boughton chest, but no colour contrast survives. 
the nave roof of Peterborough cathedral..$^{50}$ The scribe lines on the external canted edge (billets at St John's $A$ and $B$, Boughton and Norton, and chevrons at Wormshill) also presumably indicate contrasting colour (fig 24). ${ }^{5 \text { I }}$ Overall, therefore, the façades would have been visually very striking. All these examples support Eames's argument that colour was used to emphasise features of the incised design (fig 25)..$^{2}$

\section{TIMBER, DATING AND ORIGIN}

Dendrochronological analyses were conducted by Martin Bridge and Dan Miles in October 2015. Their reports are included as Appendices $\mathrm{SM}_{2}$ and $\mathrm{SM}_{3}$ of the Supplementary Material. In brief, dendrochronology and dendro-provenancing aim to identify when and where timber was growing by matching the growth patterns of samples of timber with chronologies based on previous reference samples. The results are probabilistic and their quality depends on the number of samples taken, the length of the ring sequences, the

50. Roe suggests that the arches of the Graveney chest 'were no doubt originally picked out in polychrome'. (1929, I04) The Peterborough roof boards are dendro-dated to I225-30. Harrison describes as a 'new concept' the 'shaping of some of the visible board edges with a half-round mould, and grooving some others with three shallow grooves on the front face near the outer edge of the board'. He says that: 'As these could never be seen from the ground, it is assumed that they were made to facilitate the painting of stripes along the face of these boards' $(2007,54)$. His fig 3 shows seventeenth-century, rather than original, paint on the triple grooved moulding (Hugh Harrison, pers comm, Apr 2016).

5I. The Norton chest received its buff 'grained' paint much later, probably to give the chest a uniform appearance when the pine lid was added. The open worm tracks underneath this graining suggest an earlier coat of paint.

52. Five of the other chests have fragments of paint in the incised grooves of the decoration. The St John's $A$ chest has a smooth front and sides and open worm tracks on the lid, at the bottom of the façade and the rear stiles, but not on the sides. There is off-white paint in the base of the third column and in the design in the right-hand foot. There is no doubt that it was painted at least in outline at some point. The St John's $B$ chest also has a smooth front and sides. It has open worm tracks on the front and lid but not the sides, but no signs of paint. The St John's chests have remarkably similar smooth façades, suggesting they have both been kept in good conditions and/or that the removal of paint has been relatively recent. According to Roe, 'not seven miles away from Graveney an almost identical coffer exists, still retaining much of its primary colouring' (I929, I04). This distance is compatible with Boughton, Canterbury and Norton, but the latter is unlikely since the grained paint is not original. If this teasing reference is to one of the St John's chests, which Roe described in his I9I 8 article, the colour must have been removed after I 929.

The Graveney chest has an abraded external surface and extensive open worm tracks. It has small amounts of a whitish paint in some of the incised grooves in the design of the façade. The whitish-buff paint over the open worm tracks on the right-hand side of the chest cannot be original, and the plain greyish paint behind the right front foot is also likely to be a later coat. The Boughton chest also has the remains of whitish paint in the façade design. This includes the part of the design on the later upper board, which implies that the paint is not original.

The Wormshill chest looks as though it has been scrubbed, probably prior to being exhibited in 1957. The chest was lent to Maidstone Museum in 1957 'in return for the Museum's help with cleaning and restoration work ... The cleaning consisted mainly of removing grime, and this action revealed the incised decoration' (Grove 1958, 215). The whole lid, including the replaced board, has a darkish stain probably dating from this time, but this is on top of open worm tracks, which suggests the lid had an earlier paint finish. The front and sides of the chest have been scrubbed, but there are signs of pale paint between the double outline of the four arches in the centre, in the right stile (in the gable above the arch and in the upper roundel) and in alternate rays of the whorl, suggesting early colour (see fig $2 \mathrm{I}$ ). 


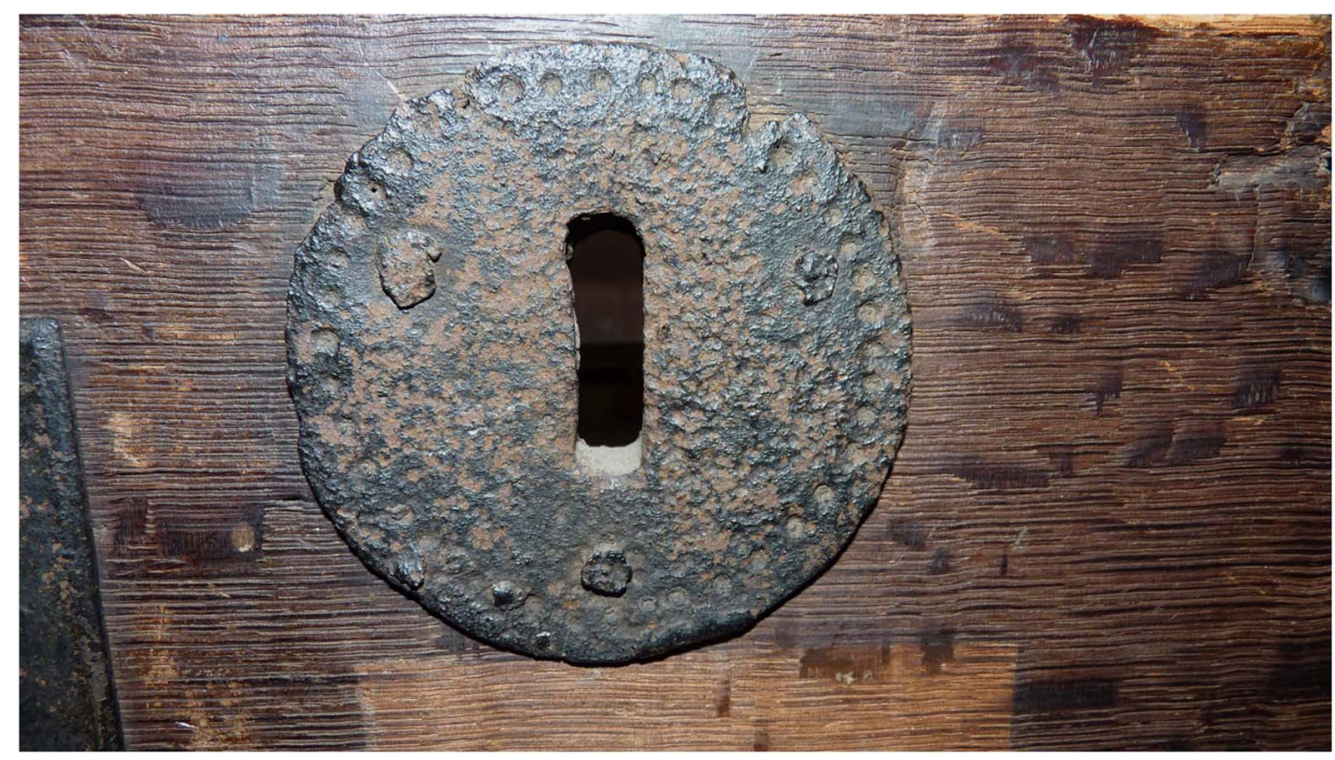

Fig 26. Iron escutcheon with punched decoration, Westminster Abbey Deep Chest.

Photograph: author.

variable geographical coverage and quality of available chronologies, and judgements about whether timber has been moved from its place of felling and whether samples are original or later additions. ${ }^{53}$ Greatest precision is achieved when bark is present (as sometimes in house timbers), medium precision when the heartwood-sapwood boundary is present (as in all four cases here), and least when heartwood only is found.

The chests were found to be of English oak and Table I shows the likely felling date ranges. ${ }^{54}$ The overlap in dates for the St John's and Graveney chests suggests that they were made roughly during the same period and before the Norton chest. ${ }^{55}$ The earliest three chests are thus among the nine earliest clamped chests to have been dendro-dated in England by 2015 - the others being at Westminster Abbey and Poslingford (Suffolk). ${ }^{56}$ The dates for the Graveney chest are particularly interesting as they are some sixty years later than the I200-20 stylistic dates given by Johnston. ${ }^{57}$ The persistence of previous styles in woodwork has been noted by many previous writers. ${ }^{58}$

53. Baillie 1982; Bridge 2012.

54. An allowance of one year for seasoning for every $2.5 \mathrm{~cm}$ of oak is usually made, so, given that the maximum thickness of the oak used is $5-6 \mathrm{~cm}$, the likely date of manufacture is two years later than the above dates (Miles 2006).

55. Another set of estimates is shown in the second column. These are based on the Bayesian Oxcal algorithm, which predicts the number of sapwood rings based on their relationship with the number of heartwood rings and mean ring width. In place of the standard 32-year felling date range used in column $\mathrm{I}$, these result in narrower range felling date ranges, of $\mathrm{I} 6-25$ years. The oneyear overlap (I257-8) between St John's $A$ and Graveney suggests the latter may be later than the former.

56. Miles and Bridge 2008; Bridge and Miles 20II.

57. Johnston 1907, 259. Likewise, Conway dated the Graveney chest to the very early thirteenth century 'because of the rudeness of its workmanship and the simplicity of its forms' (Conway 1909, 362).

58. Roe I902, 36-40; Schmitz I956, 22-5; Eames I977, 229; Charles and Veuillet 2012, I, 9I-2. 
Table I. Likely felling date range of oak in the five chests

\begin{tabular}{lcc}
\hline & Standard estimate $^{\star}$ & Oxcal estimate $^{\star \star}$ \\
\hline Arcaded Gothic chests & & \\
St John's $A$ & $\mathrm{I} 237-69$ & $1242-58$ \\
St John's $B$ & $\mathrm{I} 250-82$ & $1253-71$ \\
Graveney & $\mathrm{I} 258-90$ & $1257-80$ \\
Norton & $\mathrm{I} 302-34$ & $1302-27$ \\
Comparator chest & & \\
Yalding & $\mathrm{I} 300-20$ & \\
\hline
\end{tabular}

Source: ${ }^{\star}$ Column I, Supplementary Material 2 and 3; ${ }^{\star \star}$ Column 2, pers comm from Martin Bridge, November 2015 .

Bridge and Miles conclude that the oak is local to Kent as the chronologies for each chest correlate well with regional chronologies, but that matches with site chronologies vary in strength. ${ }^{59}$ This suggests that there is considerable diversity among the growth patterns of the oak used in Kent and that the St John's chests are made of timber probably from the same source. There is also an intriguing close match between timber on the Graveney chest and the chest at Yalding, which is $35 \mathrm{~km}$ from Graveney and $30 \mathrm{~km}$ from Canterbury. This is a plain, wide, shallow, clamped chest, which was dendro-dated to I300-20 (see Appendices SMI and SM3 in the Supplementary Material). According to Bridge and Miles: 'This may imply that the wood for the two chests came from the same source, and one may speculate that chest makers had their own supply of good timber for boards, and it is even possible that these specialist items were made in the same workshop.' (See Appendix SM3 in the Supplementary Material, p. I8.)

\section{ANALYSIS}

How distinctive is the arcaded gothic group of chests? To answer this question, the comparison group will mainly consist of pin-hinged, clamped chests likely to be thirteenth- or fourteenth-century located in Sussex, Surrey and at Westminster Abbey. ${ }^{60}$ This analysis is primarily based on the author's own recording, but reference is also made to Johnston (1907). Some Continental chests with similar features are also referred to. Since the survival rate of early chests is unknown, generalisations from the survivors are tentative. Similarities and differences are discussed in turn.

59. However, regional chronologies can produce unduly high correlations when the number of samples is large, and unwanted local effects cancel each other out (Baillie I982, 86). Correlations with oak samples from other Kent sites are therefore also relevant. The St John's chests have a strong match with the South East and 2015 Kent chronologies, but a weak one with the 1989 Kent chronology and the best site match is with a Brookland sample. This was based on few samples (Martin Bridge, pers comm, Nov 2015). The Graveney chest matches the London and both Kent chronologies (especially the 1989 one) strongly and samples from Yalding, Woodchurch and Brookland. The Norton chest has a strong match with the Southern Central chronology, but weak matches with the Kent chronologies and its best site match is with a Littlebourne sample.

60. Clamped chests are also found with iron strap hinges, but these are not discussed here. 


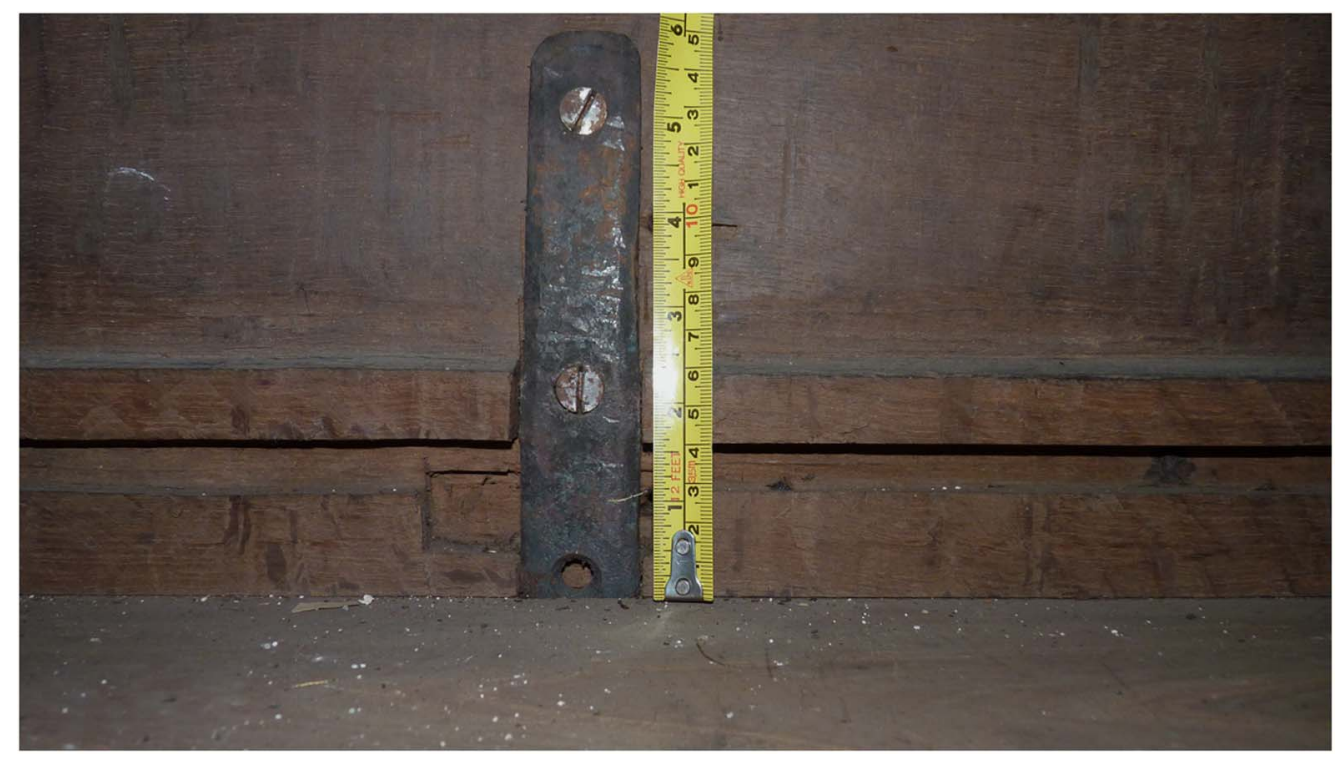

Fig 27. Canted lip and groove for bottom boards (later bottom fixed below), Salisbury cathedral chest. Photograph: author.

\section{Construction}

First, since pin hinges are a criterion for including chests in the study, they are by definition common to all chests in the comparison group. For Johnston, pin hinges were found 'only in chests constructed between the end of the twelfth and the latter part of the thirteenth century' ${ }^{61}$ In this respect he followed Roe, for whom pin hinges are 'absolutely peculiar to this period [the thirteenth century]' ${ }^{62}$ Johnston was writing prior to the existence of dendrochronology and hence based his conclusions on stylistic and documentary sources. His conclusion is consistent with the fact that all four of the pin-hinged, clamped chests at Westminster Abbey are dendro-dated before I300: the Long Chest (II70-I202), the Hutch type Chest (I237-69), the Lesser Treaty Chest (I27I-87) and the Deep Chest (I274-90). ${ }^{63}$ The St John's and Graveney chests fall within the thirteenth century and a plain example in a private collection has been dated to $c$ I300. ${ }^{64}$ The Yalding and Norton chests are, therefore, the first pin-hinged chests to be found with a likely early fourteenth-century date. A final judgement on the period over which pin hinges were used will have to wait until some of the wider group of pin-hinged, clamped chests have been dendro-dated. ${ }^{65}$ The Lüneberg Heath pin-hinged, clamped chests extend throughout the fourteenth century, from II74 to I406. ${ }^{66}$ The clamped Valère chests mostly have strap hinges. Given the

6I. Johnston 1907, 249; see also $265 \mathrm{n}$ I and 275-6.

62. Roe 1902, 19.

63. Miles and Bridge 2008.

64. Bridge and Miles 2013.

65. The plain Great Bedwyn chest at the V\&A (W.20-1920) also has pin hinges (Tracy 1988, I75), but is of much lower quality construction than the others mentioned. This may prove to be a later (I4th or I5th century) chest and would show pin hinges continuing in use when a cheap chest is required.

66. Stülpnagel 2000, chests nos 300 and 320. 
difficulty of dating strap hinges, it cannot be ruled out that some chests with pin hinges also had strap hinges from the outset.

Second, as shown earlier, the arcaded gothic chests were originally secured by a sliding bolt lock moved by a central key. The Sussex chests almost all have or had such a lock, as does the Salisbury cathedral chest - almost always with four prongs - this is clearest at Bosham, Buxted and Horsham where wooden bolt covers survive. ${ }^{67}$ This suggests that sliding bolt locks are by far the commonest original type on pin-hinged, clamped chests in Kent and Sussex. It remains to be seen whether this is true of all the wider set. The dendro dates obtained allow us to say that the use of sliding bolt locks continued into the early fourteenth century; again, further research may extend this date. Until radiographs are available, the precise design of the sliding bolts will remain unknown. A drawing of a bolt with three prongs (two cranked and one ' $U$ '-shaped) at Hatfield Broadoak, concealed in the upper frame of the façade, shows one type of sliding bolt (fig 25). A closely related fourprong bolt (three cranked and one 'U'-shaped) is on the chest at St Mary's (Polstead) - in this case without an internal wooden cover. ${ }^{68}$ Sliding bolt locks (stangenriegel) without covers are also found on a small number of Lüneberg Heath chests that are dendro-dated I26I (chest 203) to I38I (chest 4II), a much later date. ${ }^{69}$

Much confusion in the understanding of locks has been created by two assumptions: that the chests found in churches today are of one type ('church chests') and that all such chests had three locks. In fact, chests in churches are a mixture of chests commissioned by churches, chests left there for safe-keeping and chests donated or bequeathed to the church. There have been orders and edicts requiring churches to have chests with three locks at certain times and for certain purposes, with the keys held by different people: for example, those of Pope Innocent III in I 99 and Pope Clement in 1308 (both for alms). ${ }^{70}$ On the other hand, in I 66 Henry II ordered a chest to be placed in every church to collect money for the crusades, but did not specify the number of locks. The three-lock rule may have been more common in institutions as a measure against internal fraud rather than external theft. ${ }^{7 \mathrm{I}}$ But even when the rule was in force, it did not apply to every chest ordered by a church. Churches had chests for purposes not covered by these edicts (for example, to store relics and vestments). Moreover, it cannot be assumed that the edicts were always followed; the relation between bishops and cathedral chapters, for example, was often remote. ${ }^{72}$ Some previous researchers have been misled into thinking that whenever they found three locks on chests in churches, these were original. ${ }^{73}$ As Roe pointed out in 1902, 'in our earliest receptacles, however, we do not find evidence of there having been primarily more than one lock plate, the others evidently being additions of a later date' ${ }^{74}$

67. Climping, however, probably had three hasp locks (Pickvance 20I8). Johnston (1907) underestimated the frequency of sliding bolt locks, missing those at Buxted, Godalming, Midhurst and Stoke d'Abernon.

68. Pickvance 20I7c. The author wishes to thank Bill Wigglesworth and Martin Mitchell for supplying information and photos.

69. Stülpnagel 2000, II5, 266, 346 and 350 (Table 3, item 22); the chests are of the Celle and Brunswick types.

70. Lewer and Wall I9I3, 39-45; Macquoid and Edwards I954, II, 2-3; Sherlock 2008, 3-4.

7I. Sherlock 2008, 3. The author wishes to thank John Nightingale for this point.

72. Draper 1987, 83; Dobson 1995, 7I.

73. Johnston writes that 'From the close correspondence that exists between them in the different chests [in his wide survey], I am convinced that the locks and other ironwork are in nearly every case original' $(1907,306)$. In fact, he was aware of more exceptions than this suggests.

74. Roe I902, I6-I8. He was referring to the Climping, Graveney and Stoke d'Abernon chests. 
Single locks are also frequently encountered in northern Europe. Stülpnagel's survey of the fourteenth to sixteenth century, mostly tracery-, mythical- and biblical-carved chests in North German and Scandinavian museums and churches, shows them invariably to have single concave-sided lock plates located in a reserve in the design. His study of the, mostly plain, Lüneberg Heath clamped chests shows that most have a simple hasp, staple and padlock fastening, appropriate for personal furniture brought with them by the nuns. Likewise, most of the thirteenth- and fourteenth-century Valère chests have single locks. The single locks on the arcaded gothic chests are thus not at all exceptional, and this wider evidence supports the idea that the triple lock requirement was far from being universal.

Third, the evidence on minor ironwork is limited since the arcaded gothic chests have suffered losses. The Wormshill chest has the shadow of a circular escutcheon of similar size to those extant on the South Bersted chest and the Deep Chest at Westminster Abbey (see fig 26). The Buxted chest had a rectangular escutcheon and the Horsham and Laneham chests a lozenge-shaped escutcheon. ${ }^{75}$ In north Germany circular and lozenge escutcheons are also found. ${ }^{76}$ The evidence of an iron disc nailed on the lid over the ends of the staples at Graveney has parallels at Shere, where the two extant discs have raised centres. Stülpnagel shows a 1287 chest with square plates on the lid over the staple ends. ${ }^{77}$

Finally, the author's recording of pin-hinged, clamped chests in Sussex, Surrey, etc, reveals that the large majority of examples have inward-sloping sides. The rare exceptions include the Horsham and plain Winchester cathedral chests. ${ }^{78}$ This is, therefore, a feature that is not distinctive of the arcaded gothic group, but which is widely found among comparators. The reasons for exceptions to the inward-sloping 'norm' remain to be researched. ${ }^{79}$

Turning to the distinctive features of the arcaded gothic chests, the first is that all have a quarter-round upper lip above the groove holding the bottom boards. ${ }^{80}$ On the pin-hinged, clamped chests the author has recorded outside Kent, and which have an upper lip, it is generally canted. Exceptions include Horsham and Shere, where the lip is quarter-round, and the V\&A chest W.30-I926, which has the quarter-round lip at the back and the canted lip on the front and sides (figs $\mathrm{I} 3$ and 27). ${ }^{8 \mathrm{I}}$ This feature thus appears rare outside the arcaded gothic group. Some chests have grooves for the bottom boards but no lip (for example, Hindringham and the Deep Chest at Westminster Abbey). Stülpnagel shows that the walls of the thirteenth- and fourteenth-century Lüneberg Heath chests were internally shaped and show the canted lip and no lip, but not the quarter-round lip. ${ }^{82}$

A second difference is the external canted edge near the bottom of the façade, a feature not found in pin-hinged, clamped chests in Sussex and Surrey, or on the Lüneberg Heath group of chests. It provides a base frame that in some cases bears contrasting chevron or billet

75. Pickvance $2017 \mathrm{~b}$.

76. Stülpnagel 2000, IIO and II 2.

77. Ibid, 29I.

78. Pickvance $2017 \mathrm{~b}$.

79. Johnston (1907, 259) suggests that only the Ditchling, Godalming, Graveney and Chichester cathedral chests had inward-sloping sides, among those he knew of, but his own drawings correctly show inward-sloping sides on chests other than these four.

80 . The Yalding chest also has the quarter-round lip.

81. Tracy 1988, I72-4; Sherlock 2008, 59-61. The Horsham chest, at St Mary's Church, is not the one described by Johnston (1907).

82. Stülpnagel $2000,80-8$. This is all the more interesting given that the chests he studied come from four monasteries within a $40 \mathrm{~km}$ radius. What is unknown is whether the surviving Lüneberg Heath chests are typical of all such chests in north Germany at the time. If they are, the quarterround lip would indicate a real contrast. 


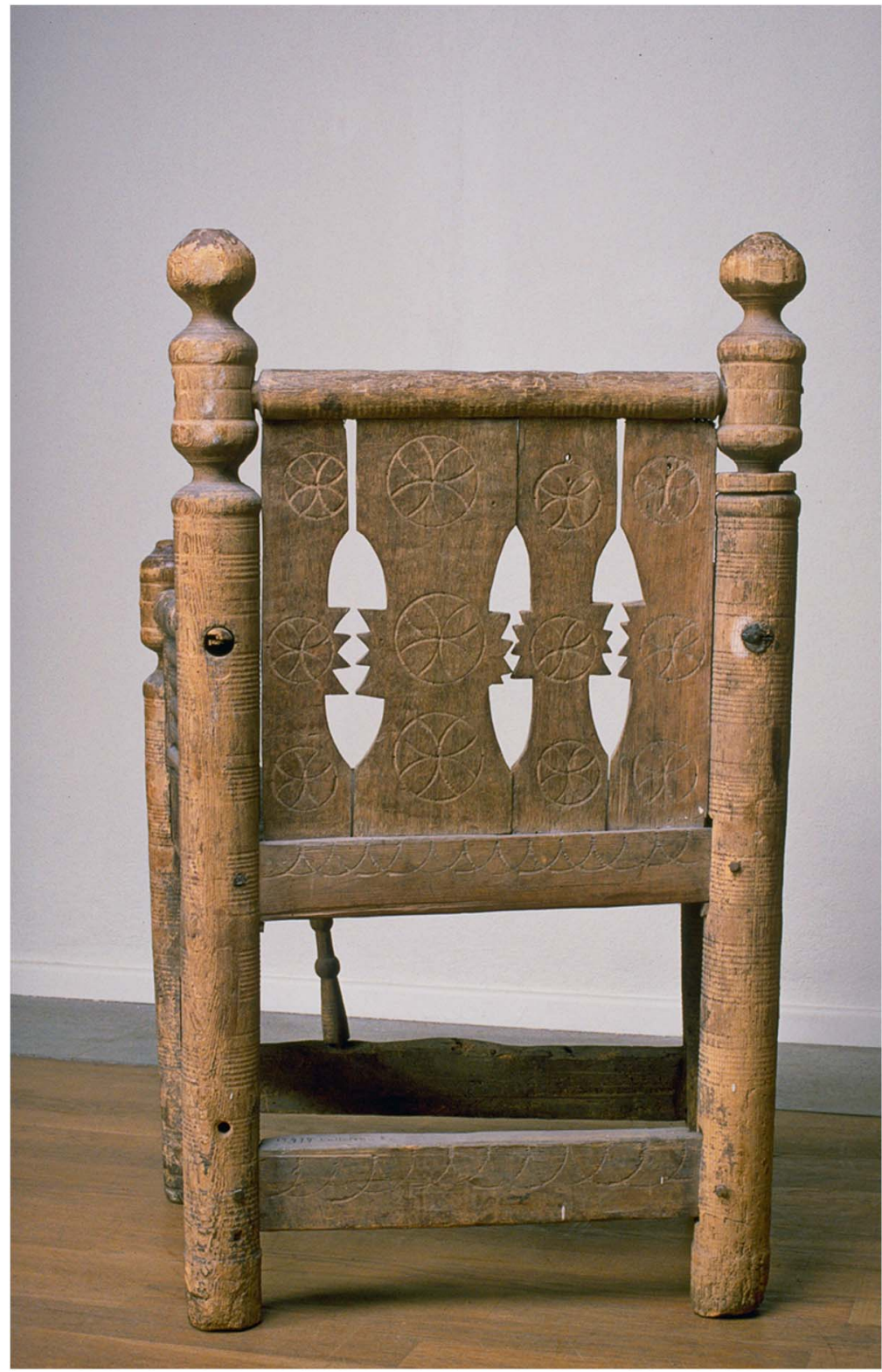

Fig 28. Swedish chair with cross pattées and intersecting round-headed arches. Photograph reproduced with permission of the Swedish History Museum, Stockholm.

decoration, and on the St John's B chest provides a base for the applied columns. Hence, it is a potentially distinctive feature of the arcaded gothic group. ${ }^{83}$

83. The author wishes to thank Nick Humphrey for this point. A chest at Cavendish (Suffolk) also has this feature, but combines it with bold trefoil arcading without columns, supporting roundels with quatrefoils, which may well be of mid-fourteenth-century Continental origin. 
A third difference is that all the arcaded gothic chests have lids and walls made of two or more $V$-jointed boards, some of which are of tapered section, whereas all but one of the Sussex and Surrey chests have a single front board: the exception is the gable-lidded Buxted ark. ${ }^{84}$ This difference may be a function of the quality of available timber. In Sussex, favourable growing conditions for oak have led to it being termed the 'Sussex weed'.

A fourth difference is that whereas iron discs or washers are found on bolt heads in East Kent for fixing the wooden bolt cover, and thus have both a functional and a decorative purpose, in Sussex and Surrey iron discs can be found used purely decoratively - for example, the row of four at Horsham (where the wooden bolt cover is nailed on from inside) or in the centre of roundels (as at Chichester cathedral and Buxted).

A final type of difference concerns features that are absent from the arcaded gothic group, but which are present on some pin-hinged, clamped chests elsewhere. The first is the 'applied grid' of battens, which are pegged to the front and back stiles and sides to reinforce these joints. These can be of two kinds: the 'incomplete' type, where the cleat attached to the lid is the top rail of the grid, and the 'complete' type, where the grid has its own top rail on top of which the cleat closes. Applied grids are a common feature on clamped chests in Sussex and Surrey where, except for the Climping chest, they are all of the 'incomplete' type. On the other hand, on pre-I500 clamped chests in northern Europe (especially north

Germany and Sweden) applied grids, where found, are typically of the 'complete' type. ${ }^{85}$ Whether this is an invariable correlation remains to be explored; it may also help to identify imported chests, or chests made according to Continental models. ${ }^{86}$

A second absence is that none of the arcaded gothic group of chests has ever had a till box with a stop-chamfered lid or with a concealed lower compartment of tapered section as found in some Surrey and Sussex chests. ${ }^{87}$ In this design, the visible bottom of the upper till box tilts or slides to reveal the lower section when a retaining peg at the side is removed; this peg is covered by a removable muntin in the applied grid that always accompanies such secret till boxes. A third absent feature is the central front-to-back batten, which is found under the bottom of some Sussex and Surrey chests and which ties the back and front together and may support the bottom. A fourth absent feature is that none of the arcaded gothic chests have iron caps or wide-headed nails over the pegs holding the front to the stiles. Such caps are found on several of the comparator chests (for example, at Bosham, Climping, Horsham, Shere and South Bersted). ${ }^{88}$

\section{Decoration}

The façades of the twenty-seven pin-hinged, clamped chests elsewhere that the author has recorded can be categorised as follows:

84. The question of when boards of tapered section were first made in England and when they were first imported is beyond the scope of this article. See Salzman 1952, 245; Simpson and Litton I996; Stülpnagel 2000; Harrison, 2007.

85. Stülpnagel 2000, 77-9, I48-96; Pickvance 2007, 2014, 2017a for imported north German examples in England.

86. It is notable that several chests with a suggested Continental origin have complete grids (Pickvance 20I4, 20I7a; V\&A W.I8-I920), as does the Cavendish chest.

87. See the drawing in Sherlock 2008, 21.

88. Pickvance $2017 \mathrm{~b}$. 
a plain: Westminster Abbey Deep Chest; Bosham (pilaster feet); Chobham (pilaster feet); St Ebbe's (Oxford); Shere (feet missing); V\&A W.20-I920; Winchester cathedral $A$; Yalding;

b plain with openwork carved column/lunette feet: Westminster Abbey Long Chest; Godalming; Rogate; Salisbury cathedral; ${ }^{89}$

c plain with relief moulded frame, with column/lunette and roundel carved in the solid on the feet: Horsham;

d two to four roundels: Chichester cathedral (lunette/column feet in solid); Earl Stonham (feet missing); Felpham; Laneham (triple gothic arch carved feet); Longstanton; Midhurst; South Bersted (feet missing); Stedham; Stoke d'Abernon (pilaster feet); V\&A W.30-I926; Winchester cathedral $B ;^{90}$

e gothic arcading and roundels: Buxted (grounded trefoil gothic arcades without columns along top of façade with flower heads and small roundels above and matching single arches on feet); Climping (full-height grounded gothic trefoil arcading with two medium roundels above, two large roundels on stiles, previously with a rectangle of honeycomb carving with nailhead border on the feet) $;^{9 \mathrm{I}}$

$\mathrm{f}$ carved intersecting round-headed arcading with applied columns, and stiles with finely incised and shaded decoration: Hindringham.

This shows that the most common form of façade decoration listed is roundels (group $d$ : eleven), that carved feet are found in groups $b$ and $c$ (five), and in pilaster form on three others in groups $a$ and $e$. Only three chests have arcading of any sort (groups $e$ and $f$ ) and these are, therefore, chosen for comparison with the incised gothic chests. Unfortunately, apart from the Westminster Abbey chests, none of the others listed has been dendrodated. ${ }^{92}$

The most striking result is that the arcaded gothic chests are unique in their main decorative feature ('outline' trefoil arches) and are the first in England, so far dated, to have gothic arcading. In Sussex, only two chests include gothic arcading (Climping and Buxted) that is carved in the solid: they also have medium-sized, chip-carved roundels rather than small, outline roundels. The St John's $B$ chest shows parallels with the Hindringham chest because both have applied columns below arcading and have small roundels.

The secondary feature of the arcaded gothic chests is the presence of roundels on the St John's $A$, Boughton, Wormshill and Norton chests. This appears to link them with the group $d$ and $e$ chests with roundels. However, the contrasts are more striking than the similarities: the arcaded gothic chests' roundels are smaller and form a minor part of a larger design dominated by arcading than the Sussex/Surrey group, where, in group $d$, chipcarved roundels are dominant. There are closer similarities between the arcaded gothic chests and the Climping and Buxted chests and a Lüneberg Heath chest dendro-dated at I260, all of which have small roundels with petals. ${ }^{93}$ Small cross pattées of the St John's $B$ type are also found on the back of the vertical slats of a turned chair from Vallstena, dated stylistically to I250-I350, in the Swedish History Museum (Inv. No. I2979) (fig 28); this

89. This is an interesting combination. Since textiles were the prime form of decoration for most furniture prior to carving and painting (Eames 1977, 229), the lack of carving on the façade above the feet may have been because it was covered with a decorative cloth.

90. The term 'roundel' is used here to include all circular motifs.

9I. For illustrations, see Roe 1902 and Johnston 1907.

92. An attempt to date the Earl Stonham chest was unsuccessful (Sherlock 2008, 59-61).

93. Stülpnagel 2000, 207 (Chest 202). 
chair has intersecting round-headed arches as on the Hindringham chest. ${ }^{94}$ Small roundels can also be seen in the margins of the Methuselah/Lamech window of I I 78 in Canterbury Cathedral. ${ }^{95}$ It is noticeable that the St John's chests show less use of roundels than the (later) Norton chest. This suggests that the preference for roundels on chests became stronger after 1300, which implies a date for the Wormshill chest close to that of the Norton chest.

None of the arcaded gothic chests has the column/lunette type of Romanesque foot decoration that is found on the otherwise plain Long Chest at Westminster Abbey, the earliest dendro-dated chest in England. Where their feet are carved, it is in the same style as the façade. Some of the Lüneberg Heath chests have openwork lunette 'feet', ranging from the elaborate (chest 200, I230) to the symbolic (chest 317,1388 ) as do the Valère chests. ${ }^{96}$

In sum, the arcaded gothic group of chests are distinct from decorated pin-hinged, clamped chests likely to be of the same period in Sussex, Surrey and elsewhere in their incised outline arcading, which is often combined with small roundels. This distinctiveness suggests that the commissioners and/or makers were stylistically advanced and had a degree of independence from those in other areas and that, whatever mobility among master craftsmen in wood took place, local workshops stuck to their own traditions. ${ }^{97}$ Thus, the author disagrees with Eames, who writes that 'not only are the similarities which shop working produces largely absent in medieval work', but the variety of furniture 'must represent the way in which labour was organized in the Middle Ages, with small groups of men who were free to produce individual solutions to different problems'.$^{98}$

\section{DO THE CHESTS HAVE A CANTERBURY ORIGIN?}

The location of all six chests in or near Canterbury is an obvious clue to their origin and this is supported by the Kentish provenance of their timber. In the thirteenth century, England experienced rapid population and economic growth and increasing income inequality, and Canterbury's population doubled in size to 8,800, making it the largest town in Kent and the ninth largest in England. North-east Kent was a rich agricultural area with specific types of land use and land tenure. Canterbury itself had numerous assets: it was the home of the premier see of England and numerous religious houses; its location gave it good links to London and, via Dover and Sandwich, to the Continent; the shrine of St Thomas à Becket attracted many pilgrims; and it possessed an important mint and significant moneylenders. The monks owned over one-third of the houses in the town as well as manors throughout and beyond Kent and, with their employees and dependants, made up Io per cent of the population. ${ }^{99}$ The average assessment for the rural deaneries of the Canterbury archdeaconry 'Spiritualities' in the Taxatio of I29I was higher than for any other archdeaconry in the Canterbury province, but was exceeded in the York province, while Canterbury

94. However, cross pattées are not otherwise found in the museum's early Swedish furniture (Pia Bengtsson Melin, pers comm, Feb 2016). Adrian Boas, author of Crusader Archaeology, has advised the author that cross pattées do not necessarily have a crusader origin (pers comm, Jun 20I6).

95. Léonie Seliger (pers comm, Aug 2015).

96. Stülpnagel 2000, 205 and 253; Charles and Veuillet 20I2, II, Chests 2-6.

97. Salzman $1952,32-54$.

98. Eames 1977, 238.

99. Urry 1956, 21, I63; Mate I984; Britnell 1996, 229; Sweetinburgh 2004; Campbell 2008, 2010. 
episcopal income $(£ \mathrm{I}, 965)$ was close to that of Ely $(£ 2,000)$, with Winchester $(£ 2,978)$ in first place. ${ }^{\text {IoO }}$

At this time, Canterbury's overseas links were extensive. Trading links between London, Cologne, Hamburg and Lubeck started in the mid-twelfth century, before the Hanseatic League had been established, and in terms of metalwork there was a ' $k$ not of connections between ... England and Lower Saxony' in the second half of the twelfth century. ${ }^{\text {IOI }}$ There were Danish, German and Flemish residents in Canterbury around I200. ${ }^{\text {IO2 }}$ Geddes links the pictorial ironwork at Staplehurst church with Swedish work in the I I50-I250 period. ${ }^{\text {IO3 }}$

The earliest clamped chests in various countries are as follows: in England, the late twelfth-century Long Chest at Westminster Abbey; in north Germany, at Lune monastery, a plain chest from I I 74; in Switzerland, at Sion, a pre-I230 chest with carved stiles (all three chests have been dendro-dated); in France, three pre-I250 chests, two with iron scrollwork stylistically dated 1200-50 at Noyon and Paris and one at Noyon dendro-dated after I225. ${ }^{\text {I0 }}$ There thus seems to have been a simultaneous emergence of such chests and it would be premature to identify a first origin, if indeed there was one. Nevertheless, the arcaded gothic chests show more contrasts than parallels with the decoration of the Continental clamped chests, so the particular form they take suggests great independence from overseas design influences.

As records of the origin of the chests are scant, we can only speculate about who commissioned them. Mercer states that the majority of pre-I300 chests are ecclesiastical in origin and links this to the 'collective wealth' and 'exceptional' situation of the 'monastic and cathedral clergy'. ${ }^{105}$ This description certainly fits Canterbury Christchurch, which was 'one of the wealthiest ecclesiastical corporations in England'. ${ }^{106}$ The Benedictine cathedral led the reception of Gothic architecture in England and the town is known to have attracted skilled craftsmen; for example, apart from a master architect and masons, it had a reputation for ivory carving and the use of gold leaf. ${ }^{107}$ It is, therefore, not unreasonable to suggest that the town had a stylistically advanced workshop capable of high quality work serving the woodwork needs of the cathedral, other religious houses and local churches as well as the wealthiest merchant and landed families. ${ }^{\text {IO } 8}$ The six chests

I0०. The Taxatio was prepared as a base on which to calculate the papal tax granted to Edward I for his planned crusade. Spiritualities are the income to benefices, which formed two-thirds of ecclesiastical income; the rest is made up of 'temporalities', or income from ecclesiastical land: Davnall et al I992, I0I-7; https://www.dhi.ac.uk/taxatio/ (accessed I8 July 2018). The author wishes to thank Paula Wolff for this reference.

IOI. Stratford 1984, 234; Postel 2007, 3.

102. Urry 1956, I7I.

I03. Geddes I999, 63, 308.

I04. Eames I977, I5I-2; Fligny I990, 4I-2; Stülpnagel 2000, 236; Bridge and Miles 20II; Charles and Veuillet 20I2, II, I6-2I; http://www.culture.gouv.fr/public/mistral/joconde_fr (accessed I8 Jul 20I8).

105. Mercer 1969, 3I and 39.

106. Dobson 1995, 70.

107. Campbell I991, I3I-2; Macgregor 1991, 377; Draper 2006. For more on craftsmen, see Ramsay I 987 and Tracy 1987.

108. Urry (I956, I2I) records seven 'carpenters' in Canterbury around I200; Salzman (I952, 32) notes that carpenters did carving too. Here 'advanced' applies to chest decoration. Trefoil arches from the twelfth century can be found on the north wall of the Great Cloister in Canterbury cathedral and in carved woodwork they appeared with small roundels above and between them on the rail in front of the 1227 choir stalls at Rochester cathedral, the earliest in England (Tracy 
could all have been made for the cathedral and religious houses and then become scattered in advance of the dissolution of Christchurch Priory, or could have been made for their current locations, or some combination of these. ${ }^{\text {IO9 }}$ Whichever is the case, the chests' shared construction and design features, and their distinctiveness compared with clamped chests in other counties, suggest that they were the product of a single workshop and one that was capable of innovation. ${ }^{\text {IIO }}$

The possibility of a cathedral origin raises the question of whether the chests can be linked to work in the cathedral at the time they were made. Canterbury cathedral's spending on land and rents throughout the thirteenth century was 'massive and continuous' and Becket's canonisation 'had elicited many other sumptuous gifts to the fabric of Canterbury cathedral'. II It was thus a perfect example of a potential ecclesiastical commissioner of new chests, as suggested by Mercer. By the mid-thirteenth century, the rebuilding of the choir and Trinity chapel was complete and the opening of St Thomas à Becket's shrine in I220 had added greatly to the renown of the cathedral. The cathedral is the place most likely to have chests of the most advanced type as part of its imposing furnishings. Woodman notes that the new choir had at least eight altars and, as mentioned earlier, it was customary for their accoutrements to be stored in chests. ${ }^{\mathrm{II} 2}$ The crypt also had altars. However, the cathedral inventory of I3I5 does not list any chests; it is incomplete and concerns only the treasures in the vestry, so does not exclude the presence of chests elsewhere. ${ }^{\mathrm{II} 3}$ The variations in the decoration and the 60-80 year date span of the chests and the smaller size and lower quality of the Norton chest could either mean that they were made for the cathedral or religious houses (though not as a single commission) or that they were made for their present buildings. ${ }^{\text {II } 4}$

The question of who financed the making of chests is hard to answer. Draper suggests that regional traditions were dominant in the design of cathedrals, not the stylistic preferences of individual patrons. ${ }^{115}$ Whether this model can be extended to fixed woodwork and chests is unknown and documentary evidence is lacking. Owners (monastic and secular) and rectors were responsible for furnishings in the choir, and the laity or churchwardens for those in the nave, with some shared responsibilities, but chests could have been found in both places and being 'responsible for' is not the same as financing. ${ }^{\text {II6 }}$ The contrast between the similar design of the arcaded gothic chests and the diversity and geographical spread of the owners and patrons of the four churches and St John's Hospital in the I250-I330 period could support the idea that these groups had only weak influence on design and that the churchwardens and laity chose chests from the presumed Canterbury

2006). The delay in the application of this motif to chests may be because most furniture at this time had low status (Mercer I969, 42; Eames I977, 228-9).

I09. They may even have been used to transport monastic treasures to safety.

I IO. For some suggestions about the movement of patrons, workers and designs, see Ramsay (I987) and Tracy (1987).

III. Mate 1984, I2, Dobson 1995, 70.

II2. Woodman 1982, 49.

II3. Legg and Hope I902, IO-II. The chests studied here were made long before Canterbury cathedral's new treasury was completed in I29I (Coldstream 2013) but are too late to be those used to store rents in the treasury (Urry I956, 38).

II4. Differences in quality are based on the details of the construction and decoration described earlier and in Appendix SMI in the Supplementary Material.

II5. Draper 2006, 40-7.

II6. Binski 2004, I76; Draper 2006, 40. 
workshop, no doubt because of their high quality and status; ${ }^{117}$ but, whatever influence commissioners had would be limited by the skills of the makers.

Finally, we return to the distinctive construction of the arcaded gothic chests to propose the hypothesis that they were chests for storing vestments. ${ }^{\text {II } 8}$ Although the dendro dates for three of the chests (I237-69, I250-82 and I258-90) precede the 1287 Exeter synod declaration, there is evidence of the earlier use of chests for books and vestments, so it is better seen as an encouragement of an existing practice than as something new. ${ }^{\text {II } 9}$ It has been suggested that copes could be stored in cope chests, cupboards or, when folded, in chests. ${ }^{\text {I2O }}$ The 1315 Canterbury Christchurch vestry inventory lists 129 copes and chasubles, which perhaps makes it more likely that all the vestments were stored there, whether in chests or not. ${ }^{\mathrm{I} 2 \mathrm{I}}$ Also, the sizes of the arcaded gothic chests is compatible with their use for vestments: apart from the Norton chest $(5 \mathrm{Icm})$, they are deeper $(68-75 \mathrm{~cm})$ than most medieval chests, their internal height ranges from $52-59 \mathrm{~cm}$, except for the Norton chest $(40 \mathrm{~cm})$, and their width ranges $128.5-157 \mathrm{~cm} .{ }^{122}$ The chests are also notable for their very smooth internal finish and for the wooden cover over the sliding bolt lock, which would have protected vestments from contact with ironwork. Clamped construction involves the skills of joinery, used in fixed woodwork but rarely on chests at this time, which can be seen as a mark of distinction in itself or as a means of producing a superior large-capacity chest for vestments. Finally, the appearance of gothic arcading on the façades of these chests - possibly for the first time in England - would be consistent with their containing something exceptional such as vestments and with the Gothic stylistic leadership of Canterbury cathedral. These arguments fall short of being conclusive but, in the absence of direct evidence, the vestment chest hypothesis is worth keeping in mind. They do not resolve the question of the cathedral or other origin of the chests, nor do they imply that clamped chests were the only type that could have been used for vestments. The rarity of clamped chests (probably under 5 per cent of all medieval chests, judging by the Essex and Suffolk county surveys) combined with their quality suggests that they are a top-of-the-range type found in cathedrals and wealthy churches, which had both the most valuable vestments requiring storage and access to craftsmen with the skills to make joined chests. ${ }^{\text {I23 }}$

II7. The owners and patrons of the four churches in the I250-I330 period were the local de Gatton and de Dene families (Wormshill), the monks of St Andrew, Rochester (Norton), the Archbishop of Canterbury (Boughton) and the Priory of St Mary Overy, Southwark (Graveney); the Archbishop of Canterbury was patron of St John's Hospital (Hasted I798, vols v, 562; vI, 409; and VII, I5 and 36).

II 8. Monnas describes the 'Great Period' of Opus Anglicanum as being from I250-I350 (2016, I5).

II9. Lewer and Wall (I9I3, 46). The author wishes to thank Peter Draper for discussion on this point. He notes that it was the debate leading up to the doctrine of Transubstantiation, and what that doctrine implied for the solemnity of the Mass, at the 1215 Fourth Lateran Council, that was the main factor in the increasing number (and elaboration) of vestments and liturgical plate, all of which would have needed to be securely stored. (pers comm, Mar 2018).

I20. Davies 2016, I44.

I21. Legg and Hope I902, 26. In I 546, St John's Hospital chapel possessed three copes, I5 vestments and 29 altar cloths, but it is not specified where these were kept (Holland I934, I9).

122. Of the 18 copes and chasubles in the Opus Anglicanum exhibition held at the V\&A in London from I Oct 2016 to 5 Feb 2017 , I 5 are II $5-149 \mathrm{~cm}$ and three $162-9 \mathrm{~cm}$ long; they may have been above average in length as well as quality (Browne et al 20I6).

123. The shallower chest at Norton may correspond to the small size of that church. 


\section{CONCLUSION}

This paper has identified the distinctive constructional and decorative features of the arcaded gothic chests in the Canterbury area as well as those shared with pin-hinged, clamped chests elsewhere. The use of dendrochronology has allowed us to date these features and correct earlier stylistic dates, to extend dates for the use of pin hinges and sliding bolt locks into the early fourteenth century and to show that single locks were the norm on clamped, pin-hinged chests in Kent and Sussex. Comparison has allowed us to identify both shared and distinctive constructional and decorative features of the arcaded gothic chests relative to those in Sussex, north Germany, Switzerland and France. Overall, it has been suggested that the chests' distinctive features suggest that they were made by craftsmen working in traditions that developed with some independence from work in adjacent counties and Continental work. It would appear that Canterbury, home of the first English Gothic cathedral, developed, with a lag, a closely related novel style of chest decoration. It is thus reasonable to describe the arcaded gothic group of chests as the Canterbury group. Whether the group will prove to be the earliest extant chests in England with gothic arcading depends on future dendrochronological research.

Many puzzles remain. Was the combination of clamped construction, pin hinges and a sophisticated locking system seen as equally safe as boarded construction with extensive iron strapwork and hasp locks? If not, were clamped chests located in rooms that had additional protection (for example, vestries or treasuries) or that were locked from the inside? ${ }^{\mathrm{I} 24}$ Is the vestment chest hypothesis tenable, or did clamped chests have a variety of uses? Was a key point about clamped chests that they offered great scope for carved decoration compared with iron-bound chests, thus allowing the transition of arcading from stonework to furniture? If so, this would have allowed them to match the decor of the spaces where they were kept.

There are also many more general questions for further research concerning the commissioning process, workshop organisation and labour mobility, the relation between buildings, rooms and chests, medieval carpentry (timber conversion, tapered section boards, imported timber, moulding patterns) and the various specific features of construction, decoration, locks (types and number) and other ironwork, and the nature and direction of international (for example, monastic) influences. It is hoped that this article will help in exploring these topics and will provide a base line for future researchers to test its conclusions against clamped chests in other counties and countries.

\section{SUPPLEMENTARY MATERIAL}

Supplementary material for this article is available online and can be found at https://doi. org/I0.IOI7/So003581518000562

\section{ACKNOWLEDGEMENTS}

The author is very grateful to the following organisations for funding the dendrochronological analysis: Marc Fitch Fund, Regional Furniture Society, Kent Archaeological Society and

I24. For an insightful analysis of access and security in medieval cathedrals, see Draper (2003). 
Furniture History Society. For the dendrochronological study, the author wishes to thank Martin Bridge and Dan Miles. For access to chests, the author also wishes to thank Stanley Denham and Sharon Keenor (St John's Hospital), Gill and Peter Reed (Graveney), Steve Lillicrap (Norton), Hilary and John Nightingale (Wormshill), Alison Smith and Ray Watson (Boughton), Alan Bott (Godalming), Ray Buller (Hindringham), Nick Humphrey (V\&A), Michael Moriarty (Chichester cathedral), Emily Naish (Salisbury cathedral) and Matthew Payne (Westminster Abbey); and, for a photograph, Katarina Nimmervoll (Swedish History Museum). For their valuable advice and support, the author is indebted to Peter Draper, David Sherlock, Sheila Sweetinburgh and Charles Tracy, and also to Adrian Boas, Martin Bridge, Roderick Butler, Jaroslav Folda, Jane Geddes, Hugh Harrison, Nick Humphrey, Pia Bengtsson Melin, John Nightingale, Didier Pousset, Noël Riley, Alicia Robinson, Léonie Seliger, Karl Heinrich von Stülpnagel, Beryl Taylor, Joe Thompson and Paula Wolff. An earlier version of this article benefited greatly from a thorough reading by Nick Humphrey.

\section{ABBREVIATIONS AND BIBLIOGRAPHY}

\section{Abbreviations}

RA Royal Academy of Arts, London

V\&A Victoria \& Albert Museum, London

\section{Bibliography}

Alexander, J A and Binski, P (eds) 1987. Age of Chivalry, RA, London

Baillie, M G L 1982. Tree Ring Dating and Archaeology, University of Chicago Press, London and Chicago

Baumeier, S 2012. Beschlagene kisten: Die alteste truhen Westfalens, Klartext Verlag, Essen

Binski, P 2004. Becket's Crown: art and imagination in Gothic England II70-I300, Yale University Press, London

Blair, J and Ramsay, N (eds) I991. English Medieval Industries, Hambledon, London

Boas, A J 20 I6. Crusader Archaeology, Routledge, London

Boorman, H R P and Tarr, V J I954. Kent Churches, Kent Messenger, Maidstone

Bridge, M 20I2. 'Locating the origins of wood resources: a review of dendroprovenancing', 7 Archaeol Sci, 39, 2828-34

Bridge, M C and Miles, D W H 20I I. 'A review of the information gained from dendrochronologically dated chests in England', Reg Furniture, 25, 25-55

Bridge, M C and Miles, D W H 2013. The TreeRing Dating of an Early English Oak Chest, Oxford Dendrochronology Laboratory, Mapledurham

Britnell, R H 1996. The Commercialisation of English Society 1000-1500, Manchester University Press, Manchester

Browne, C, Davis, G and Michael, M (eds) 2016, English Medieval Embroidery: Opus Anglicanum, Yale University Press in association with the V\&A Museum, New Haven and London

Campbell, B M S 2008. 'Benchmarking medieval economic development: England, Wales, Scotland and Ireland, circa I290', Econom Hist Rev, 6I, 896-945

Campbell, B M S 2010. 'Agriculture in Kent in the High Middle Ages', in S Sweetinburgh (ed), Later Medieval Kent 1220-1540, Boydell, Martlesham

Campbell, M I99I. 'Gold, silver and precious stones', in J Blair and N Ramsay I99I

Cescinsky, $\mathrm{H}$ and Gribble, E R 1922. Early English Furniture and Woodwork (2 vols), Waverley, London

Charles, C and Veuillet, C 2012. Coffres et coffrets du Moyen Age dans les collections du Musée d'histoire du Valais, Sion, 2 vols, Hier und Jetzt, Baden and Musées cantonnaux de Valère, Sion

Chinnery, V 1979. Oak Furniture: the British tradition, Antique Collectors' Club, Woodbridge

Coldstream, N 2013. 'The Nova Opera of Prior Henry of Eastry', in A Bovey (ed), Medieval Art, Architecture and Art at Canterbury, Maney, Leeds 
Conway, M i909. 'Some Kentish chests', Burlington Mag, I5 (78), 362-7

Cox, J C and Harvey, A 1908. English Church Furniture, 2nd edn, Methuen, London

Davies, G 20I6. 'Cope chest', in C Browne et al 20I6, I23-4

Davnall, S, Denton, J, Griffiths, S, Ross, D and Taylor, B I992. 'The Taxatio database', Bull fohn Rylands Libr, 74 (3), 89-108

Dobson, B I995. 'The monks of Canterbury in the later Middle Ages', in P Collinson, N Ramsay and M Sparks (eds), A History of Canterbury Cathedral, Oxford University Press, Oxford

Draper, P I987. 'Architecture and liturgy', in Alexander and Binski 1987

Draper, P 2003. 'Enclosures and entrances in medieval cathedrals: access and security', in J Backhouse (ed), The Medieval English Cathedral: papers in honour of Pamela Tudor-Craig, Shaun Tyas, Donington

Draper, P 2006. The Formation of English Gothic, Yale University Press, London

Duncombe, J and Battely, N 1785 . The History and Antiquities of the Three Archiepiscopal Hospitals and other Charitable Foundations at and near Canterbury, St Augustine's College, Canterbury

Eames, P 1977. 'Furniture in England, France and the Netherlands from the twelfth to the fifteenth century', Furniture Hist, $\mathbf{1 3}$, I-303

Fligny, L 1990. Le mobilier en Picardie I200-I700, Picard, Paris

Geddes, J I999. Medieval Decorative Ironwork in England, Society of Antiquaries of London, London

Geddes, J and Sherlock, D i987. 'The church chests at Icklingham, Suffolk and Church Brampton, Northamptonshire', Proc Suffolk Inst Archaeol Hist, 3I, 202-6

Grove, L R A I958. 'A chest of thirteenthcentury type from Wormshill church', Archaeologia Cantiana, 7I, 214-8

Harrison, $\mathrm{H}$ 2007. 'Church woodwork in England', Reg Furniture, 2I, 53-66

Hasted, E 1798. The History and Topographical Survey of the County of Kent, 2nd edn, Simmons and Kirkby, Canterbury

Hewitt, C 1980. English Historic Carpentry, Phillimore, London

Holland, E (transl) 1934. The Canterbury Chantries and Hospitals in 1546, Together with Some Others in the Neighbourhood: a supplement to Kent chantries, Kent Archaeological Society, Ashford
Howard, F E and Crossley, F H 1927. English Church Woodwork, 2nd edn, Batsford, London

Jennings, C 1974. Early Chests in Wood and Iron, HMSO, London

Johnston, P M 1907. 'Church chests of the twelfth and thirteenth centuries in England', Archaeol f, 64, 243-306

Legg, J W and Hope, W H St J (eds) 1902. Inventories of Christchurch Canterbury with Historical and Topographical Introductions and Illustrative Documents, Archibald Constable, London

Lewer, H W and Wall, J C i913. The Church Chests of Essex, Talbot, London

Macgregor, A I99I. 'Antler, bone and horn', in J Blair and N Ramsay I99I

Macquoid, P and Edwards, R (eds) 1954. Dictionary of English Furniture, 3 vols, Antique Collectors' Club, Woodbridge

Mate, M 1984. 'Property investment by Canterbury Cathedral priory 1250-I400', f Brit Stud, 23 (2), I-2 I

Mercer, E 1969. Furniture 700-I700, Weidenfeld and Nicholson, London

Miles, D W H 2006. 'Refinements in the interpretation of tree-ring dates for oak building timbers in England and Wales', Vernac Architect, 37, 84-96

Miles, D W H and Bridge, M C 2008. Westminster Abbey, London: tree-ring dating of the chests and fittings, Engl Heritage Res Dept Ser 3/2008, Portsmouth

Monnas, L 20I6. 'The making of medieval embroidery', in C Browne et al 2016

Morgan, F C 1947. 'Church chests of Herefordshire', Woolhope Naturalists' Field Club Trans, 32, I22-43

Newman, J H 2002. North East and East Kent, Yale University Press, London

Pickvance, C G 2007. 'Medieval tracery-carved clamped chests: the "Kentish Gothic" chests of Rainham, Faversham and Canterbury in comparative perspective', Reg Furniture, 2I, 67-94

Pickvance, C G 20I2. 'Medieval domed chests in Kent: a contribution to a national and international study', Reg Furniture, 26, I05-47

Pickvance, C G 20I4. 'The tracery-carved, clamped, medieval chest at St Mary Magdalen Church, Oxford, in comparative North-West European perspective', Antiq $\mathcal{F}$, 94, I53-7I

Pickvance, C G 2015. 'A study of medieval ironbound "domed standard" chests in Kent', Archaeologia Cantiana, 136, I4I-62 
Pickvance, C G 20I7a. “"Kentish Gothic” or imported? Understanding a group of early I 5 th century tracery-carved medieval chests in Kent and Norfolk', Archaeologia Cantiana, 138, 105-28

Pickvance, C G 20I7b. 'The medieval chest at St Mary's church, Horsham: an important unrecorded pin-hinged, clamped chest', Sussex Archaeol Collect, 155, 203-7

Pickvance, C G 2017c. 'The medieval chest at St Mary's church, Polstead, Suffolk', unpublished report

Pickvance, C G 2018. 'The St Mary's, Climping, and Chichester Cathedral medieval chests: a dendrochronological and comparative study', unpublished report

Postel, R 2007. 'The Hanseatic League', Lecture at Gresham's College, London http://www.gresham.ac.uk/lectures-andevents/part-one-the-hanseatic-league-andother-uk-hansa-towns (accessed I8 July 2018)

Ramsay, N 1987. 'Artists, craftsmen and design in England, I200-I400', in Alexander and Binski 1987

Roe, F 1902. Ancient Coffers and Cupboards, Methuen, London

Roe, F I9I8. 'Some curious antique coffers', The Connoisseur, 5I, 77-85

Roe, F I920. 'History of oak furniture', The Connoisseur, London

Roe, F 1929. Ancient Church Chests and Chairs, Batsford, London

Salzman, L F 1952. Building in England Down to 1540, Clarendon Press, Oxford

Schmitz, H 1956. The Encyclopedia of Furniture, Zwemmer, London

Sherlock, D 2008. Suffolk Church Chests, Suffolk Institute of Archaeology and History, Ipswich

Sherlock, D 20II. 'The Prittlewell chest panels and a group of English church chests decorated with tracery and bestiaries', Trans

Essex Soc Archaeol Hist, 2, I73-87

Simpson, W G 2008. 'The pine standard chest in St Margaret's Church, King's Lynn and the social and economic significance of the type', Brit Archaeol Ass Trans, 3I, 53-65

Simpson, W G and Litton, C D 1996.

'Dendrochronology in cathedrals', in

$\mathrm{T}$ Tatton-Brown and J Munby (eds), The

Archaeology of Cathedrals, Oxford University Committee for Archaeology, Oxford

Stratford, N I984. 'Metalwork', in G Zarnecki, $\mathrm{J}$ Holt and T Holland (eds), English Romanesque Art 1066-I240, Arts Council of Great Britain, London

Stülpnagel, K H von 2000. Die Gothische Truhen der Lüneberger Heidekloster, Museumsdorf Cloppenburg, Cloppenburg

Sweetinburgh, S 2004. 'Landholding in 1300', in T Lawson and D Killingray (eds), $A n$ Historical Atlas of Kent, Phillimore, Chichester

Tracy, C 1987. 'Woodwork', in Alexander and Binski 1987

Tracy, C 1988. English Medieval Furniture and Woodwork, V\&A, London

Tracy, C 200I. Continental Church Furniture in England: a traffic in piety, Antique Collectors' Club, Woodbridge

Tracy, C 2006. 'The early thirteenth-century choir-stalls and associated furniture at Rochester cathedral', in T Ayers and T Tatton-Brown (eds), Medieval Art, Architecture and Archaeology at Rochester, Manley, Leeds

Underhill, T i915. 'Notes of the month', Antiquary, II (Feb), 42-3

Urry, W 1956. Canterbury Under the Angevin Kings, Athlone Press, London

Woodman, F 1982. The Architectural History of Canterbury Cathedral, Routledge and Kegan Paul, London 